\title{
Environmental Awareness and Sensitivity of the Gifted Students: "Science and Art Explorers in The Nature"
}

\author{
Yakup-AYAYDIN ${ }^{\mathrm{A}}$, Duygu ÜN ${ }^{\mathrm{b}}$, Burçin ACAR ŞEŞEN*c ${ }^{*}$, Seda USTA GEZER ${ }^{\mathrm{d}}$, Sezen \\ CAMCI ERDOĞAN ${ }^{\mathrm{e}}$
}

\begin{tabular}{l} 
Article Info \\
\hline DOI: $10.14686 /$ buefad.379723 \\
\hline Article History: \\
Received: $\quad 16.01 .2018$ \\
Accepted: $\quad 15.04 .2018$ \\
Published: $\quad 30.06 .2018$ \\
\hline Keywords: \\
Environmental education, \\
Environmental sensitivity, \\
Environmental awareness, \\
Gifted students \\
\hline Article Type: \\
Research article
\end{tabular}

\begin{abstract}
In this study, it was aimed to investigate the effect of the six days nature education which was named TUBITAK 4004 "Science and Art Explorers in The Nature" and was organized to improve the environmental awareness and sensitivity of the gifted students, on environmental awareness and concerns of the students. 50 seventhgrade gifted students from Istanbul, Aydin and Tekirdağ were participated in this study. The study was conducted as qualitative study and as data collection tools, two questionnaires consisting of seven open-ended questions were used to determine the environmental awareness and concerns of the students. The data was analysed by descriptive analysis method. After the activities carried out during the project period, it has been determined that the awareness and concerns of the students about the environment consciousness and the environment have improved. Students have stated that environmental education is fun, they learn a lot about the environment, living things and ecosystems together by the activities that they made and they are now more sensitive about protecting the environment.
\end{abstract}

\section{Özel Yetenekli Öğrencilerin Çevre Farkındalık ve Duyarılılıları: "Bilim ve Sanat Kâş̧ifleri Doğada"}

\begin{tabular}{|c|c|}
\hline \multicolumn{2}{|c|}{ Makale Bilgisi } \\
\hline \multicolumn{2}{|c|}{ DOI: $10.14686 /$ buefad.379723 } \\
\hline \multicolumn{2}{|c|}{ Makale Geçmişi: } \\
\hline Geliş: & 16.01 .2018 \\
\hline Kabul: & 15.04 .2018 \\
\hline Yayın: & 30.06 .2018 \\
\hline \multicolumn{2}{|c|}{ Anahtar Kelimeler: } \\
\hline \multicolumn{2}{|c|}{$\begin{array}{l}\text { Çevre eğitimi, } \\
\text { Çevre farkındalığı, } \\
\text { Çevre duyarlığ } 1 \text {, } \\
\text { Özel yetenekli ögrenciler }\end{array}$} \\
\hline $\begin{array}{l}\text { Makale } \\
\text { Araştırı }\end{array}$ & kalesi \\
\hline
\end{tabular}

\section{Öz}

\begin{abstract}
$\mathrm{Bu}$ çalışmada, özel yetenekli öğrencilerin çevre farkındalık ve duyarlılıklarını geliştirmek amaciyla düzenlenen TÜBİTAK 4004 "Bilim ve Sanat Kâşifleri Doğada" adlı altı gün süren doğa eğitimi projesinin, öğrencilerin çevreye yönelik farkındalık ve duyarlılıkları üzerine olan etkisinin araştırılması amaçlanmıştır. Araştırmaya İstanbul, Aydın ve Tekirdağ illerinden 50 özel yetenekli yedinci sınıf öğrencisi katılmıştır. Nitel yöntemin kullanıldığı çalışmada, veri toplama aracı olarak öğrencilerin çevre farkındalık ve duyarlılıklarını belirlemek amacıyla yedişer açık uçlu sorudan oluşan iki anket kullanılmıştır. Veriler betimsel analiz yöntemiyle analiz edilmiştir. Proje sürecinde doğa ile ilgili yapılan etkinliklerden sonra öğrencilerin çevre bilincinin, çevreye yönelik farkındalık ve duyarlılıklarının geliştiği tespit edilmiştir. Öğrenciler çevre eğitimlerinin eğlenceli olduğunu, yapılan etkinliklerle birlikte çevre, canlılar ve ekosistem ile ilgili birçok bilgi edindiklerini, çevreyi koruma konusunda artık daha duyarlı olduklarını belirtmişlerdir.
\end{abstract}

*Corresponding Author: bsesen @istanbul.edu.tr

${ }^{a} \mathrm{PhD}$ student, Marmara University Educational Sciences Institute, Istanbul/Turkey, https://orcid.org/0000-0001-5710-4626

b PhD student, Istanbul University Educational Sciences Institute, Istanbul/Turkey, https://orcid.org/0000-0002-3937-7759

${ }^{c}$ Assoc. Prof., Istanbul University, Hasan Ali Yücel Faculty of Education, Science Education Department, Istanbul/Turkey, https://orcid.org/0000-0002-1585-0441

d Asst. Prof., Istanbul University, Hasan Ali Yücel Faculty of Education, Science Education Department, Istanbul/Turkey, https://orcid.org/0000-0002-7505-0024

e Asst. Prof.., Istanbul University, Hasan Ali Yücel Faculty of Education, Gifted Education Department, Istanbul/Turkey, https://orcid.org/0000-0002-5059-9168 


\section{Introduction}

Environmental issues have become one of the most important problems in today's world. Many subjects regarding environment from the air we breathe to water we drink, from forest fires to soil pollution have become important agenda for our daily life. Environmental issues are not a problem that can be solved only by technology or laws even though several legal and technological actions have been taken in order to overcome environmental issues (Erten, 2003). Key concept to solve environmental issues reflects as the education of individuals who create the society. Precondition to go into action for environment is to be aware of environmental issues. Therefore, the most important component to war with environmental degradation on a global scale appears as an effective environmental education both in formal and informal senses (Taylor \&diğ., 2009).

For Zeleny and Schultz (2000), individual responsibilities and behavioral change are the most important factor to solve environmental crises. To change behaviors in desired direction requires educating the people. Environmental education, which starts in family, continues in schools and the society we live in. The thing is to allow children to meet nature and gain a love of nature as from the early ages (Birinci, 2007). At the age which people can learn most quickly and reflect what they learn on their behaviors, first hands-on training should be concentrated on and students should be enabled to learn by performing, feeling, experiencing (Sarıkaya, 2007).

Conference called "Environmental Education in School Programs" made a great contribution to develop environmental education, which it was arranged by International Union for Conservation of Nature-IUCN in Nevada in 1970. In this conference, "environmental education" was defined as "the process to explain concepts and to notice values in order to comprehend relationship between people, cultures and biophysical environment and develop the required attitudes and skills" (IUCN, 1970) and this definition has been accepted by many institutions in many countries (Neal \& Palmer, 1994). Purpose of the environmental education is to raise individuals who would consume as much as the needs, accept responsibility for the next generations, be sensitive to and conscious to environmental issues, have positive and permanent behavioral changes, ensure active participation in solving problems (Şimşekli, 2004) and could make proper decisions on environment and show proper attitudes (Hart, 2007). In creating environmental awareness and sensitivity in the society, we need individuals who will be leader and can take responsibility in these roles in terms of conducting remarkable studies. In this point, gifted students are considered as resources which should be encouraged at the point of offering solutions regarding problems about nature and all living creatures especially because of their intense sensitivity to global issues (Piechowski, 1997) and their high level abilities to solve and pose problems (Mönks, Heller \& Passow, 2002). The reason is that gifted students have natural interests in natural environment as it stimulates their senses of wonder and imaginations (Smutny \& VonFremd, 2004) and they are interested in negative changes emerging in the environment (Lovecky, 1993). In addition, gifted students have highly advanced discernments, which a good discernment should be available in relation to demonstrate the conditions that are harmful to natural environment and why it should be saved (Sisk, 2007). Thus, gifted students potentially offer solutions for these problems while they encounter several global problems (Çağlar, 1972).

Environmental education is an interdisciplinary field of study. They have both cognitive and affective areas. While their purposes on cognitive field have made for allowing people to be environmental literate further, their purposes on affective field create values and attitudes to environment and environmental issues (Budak, 2008). In addition to that, attitudes, information and value judgments may change positively when individual behaviors on environment change (Erten, 2005). Gifted students know very different truths about nature and science and understand deeply the concepts they learn in science (Gould, Weeks \& Evans, 2003) and they have also insight and understanding in relation to transfer what they have learned from specific examples to more general examples (Kopelman, Galasso \& Strom, 1977; Ngoi \& Vodracek, 2004). They get this information by observing their environment closely (Karnes \& Riley, 2005), noticing and defining the problems everybody else have ignored (Meador, 2003) and enjoying researches on open-ended problem statuses. Therefore, they are more sensitive to the environment they live in and they are also more sensitive and active to notice the problems experienced in this environment and offer solutions than their peers. When it is considered that they are individuals who can actually take responsibilities at this point because of their sensitivity to nature and environment and their eagerness to offer solutions for the current problems, it is important to what extent these students aware of and sensitive to environment. In this context, certain quantitative studies on environment have been carried out with gifted students in our country. 
While Esen (2011) studied examination on environmental knowledge of gifted students and their attitudes to environment by gender, class level and socio-economic level; Aydın, Coşkun, Kaya \& Erdönmez (2011), similarly, studied examination on attitudes of gifted students to environment by gender, class level, etc. variables. While Bakar and Aydinl (2012) studied attitudes of gifted students to recycling and environmental effects of plastic wastes in terms of gender, class level, etc. variables, Uğulu, Akkaya \& Erkol (2013) studied attitudes of gifted students to environment by gender, age and class variables. Differently from other studies, Uğulu (2013) and Sontay, Gökdere \& Usta $(2014 ; 2016)$ carried out studies to compare gifted students with their peers with normal mind levels in terms of their attitudes to environment, environmental literacy components and environmental behaviors. As is seen, these previous studies were carried out generally in two different ways. Although certain studies are quantitative studies that examine variables like environmental attitudes of gifted students and their knowledge of environment, etc. in terms of demographical properties like gender, class level, socio-economic level, etc., a group of studies examine comparison of variables like environmental attitudes, environmental literacy statuses, environmental behaviors of gifted students and students with normal mind levels. However, there is no study on increasing awareness and sensitivity of gifted students to the current environment and making them more effective. Whereas Winocur \& Maurer (1991) stated that high level thinking skills of gifted students would develop and interests of students in global issues may increase by means of educations on environment, protection of environment, environmental issues, etc. When gifted individuals get more information, they are concerned about global environmental issues we encounter and then they show sensitivity and create interests for solution (Clark, 1992). So, when gifted students get proper education on environment, they can be protectors for important decisions to make on environment or environmental applications (Esen, 2011). In this context, purpose of the current study is to determine whether environmental education provided for gifted students within the scope of project has created a change in awareness and sensitivity of the students to the environment, or not, and to examine its efficiency. When the literature is examined, it is seen that studies in which environmental awareness and sensitivity of individuals are determined are mainly based on quantitative research method. Besides, it is thought that the current study to carry out qualitatively would make contribution to studies on whether educations on environment and environmental issues have influence on environmental awareness of gifted students, their environmental sensitivity, environmental attitudes.

\section{Method}

Case study design that is one of the qualitative research methods has been used in the study. The study examines the extent of environmental awareness and sensitivity levels for gifted students and how did they change by the applied environmental education project. In the study, TÜBİTAK project called "Science and Art Explorers are in Nature" was carried out in order to develop awareness and sensitivity of gifted students. Within the scope of the project, six-day training was conducted in Istanbul University, Bahçelievler Science and Art Center and Belgrad Forest through the activities developed by academicians and teachers. During the research, hands-on activities were performed by which gifted students would notice role of physics, chemistry, biology and math in the nature and their natural beauties inspiring to the art and develop awareness and sensitivity to the environment. Surveys developed as data collection tools were applied on students as pre-test before the training and post-test after the application.

\section{Work Group}

50 gifted students participated in the research in total; 40 from Istanbul and 5 each from Aydın and Tekirdağ provinces. Criterion sampling method was used in selection of students. Criteria were considered as being defined as gifted, gender, making an application to the project, passing the grade 7 . All of the participants were selected among the students defined as gifted by Counseling and Research Center allied with the Ministry of National Education. 25 of the participants were male and 25 were female students. Answers from 6 students were not included in the analysis because of absence during the research period, non-participation in the pre and post application.

\section{Data Collection and Analysis Methods}

Two surveys consisting of 7 open-ended questions were used as data collection tool to determine environmental awareness and sensitivity of students. Survey prepared by the researchers was put into final form by taking opinions and recommendations from 3 each academician who was specialists in Physical Science Education and 
Education for Gifted People. Survey applied before training aimed to determine expectations of students from the training provided within the scope of project and their awareness and sensitivity to the environment. As for survey applied after the training, it was applied to examine effects of activities within the scope of project on environmental awareness and sensitivity of the students. Before analyzing, the obtained data was written on Word program and it was turned into a text. The obtained data was analyzed by descriptive analysis method. The obtained data was presented by themes formed based on survey questions. Coding was done by the categories developed by the themes. Direct quotations were included in the study in order to reflect opinions of the individuals.

\section{Findings}

\section{Expectations of Gifted Students from Environmental Education Project}

In the study, "What are your expectations from the activities within the scope of "Explorers in Nature" Project?" question is addressed concerning the expectations of students from environmental education project before the application. Table 1 includes findings obtained by answers from the students.

Table 1. Expectations of Gifted Students from Environmental Education Project

\begin{tabular}{lc}
\hline Statements & Pre-application (percentage) \\
\hline Knowledge of nature/Acknowledgement of nature & 52,2 \\
Nature/environment consciousness & 18,1 \\
Exploring the nature & 11,3 \\
Sensitivity to nature & 9 \\
Learning outcomes about Art and Science & 9 \\
Teaching what we should do to protect the nature & 6,8 \\
Teaching the ecosystem & 6,8 \\
Developing a new perspective & 4,5 \\
I don't know & 4,5 \\
New experiences & 4,5 \\
Love of nature & 4,5 \\
Nature awareness & 4,5
\end{tabular}

When examining findings in Table 1, more than half of students have stated that activities involved in the project would contribute them to know about nature and get information on the nature. In addition, students think that project would make contributions such like environmental consciousness, environmental sensitivity, environmental awareness, exploring the nature, developing new perspectives, love of nature, teaching the ecosystem, bringing new experiences and teaching what they should do to protect the nature. When opinions of the students are examined in this regard, Participant 7 has stated that project would allow them to get more information on the nature by using the statement "It would make possible to get more information on the nature". Participant 40 has emphasized that project would allow them to get information on nature and take an interest in nature by using the statement "I am hoping that it would examine closely creatures in the nature and then give me more information on them, enlighten me about certain issues I don't know and make me closer to the nature ". Participant 11 has emphasized that the project would inform him/her on nature as well as it would allow him/her to become conscious of nature by using the statement "I am hoping this project would raise the awareness of me and give me some information on nature". Participant 28 has emphasized that project would bring achievements in art and science as well as an awareness of environment by using the statement "I expect my consciousness of nature and environment would increase especially and I would have gains in art and science". Participant 39 has emphasized that project would bring an environmental consciousness and allow us to explore the nature by using the statement "I aspire to explore hidden beauties of the nature and experience that piece. I expect I would be much closer to the nature and it will show me environmental consciousness and advantages of the environmental 
consciousness". Participant 35 has stated that project would increase environmental sensitivity by using the statement "I hope it makes us aware of things around us and increases the sensitivity". Participant 6 has emphasized that project would make a contribution to develop a new perspective by using the statement "having an enjoyable time without technology, exploring the nature, developing a new perspective of nature".

\section{Environmental Sensitivity of Gifted Students}

In the study, "Do you think you are an individual sensitive to environment? What do you do to show your sensitivity? Do you think all things you've done are enough to create a sustainable environment?" questions are addressed to the students. Table 2 includes findings obtained by answers from the students in pre-test and posttest.

Table 2. Opinions of Gifted Students on Environmental Sensitivity

\section{Category}

\section{Percentage distribution}

\section{Pre-application}

I don't damage the nature

I help the animals

I warn those who pollute the nature

What I've done is enough for a sustainable environment

I raise awareness of people

I save the energy

I try to use natural resources less

I recycle

I protect the environment

I don't damage creatures

I'm not sensitive to environment

I protect the animals

I can join civil society organization

I'm more sensitive with the project

All humanity should struggle for our environment.

I've understood that I damaged the world more after the project

I've understood that I should do more things for environment.
61,3

\section{Post- application}

43,1

$-$

9

29,5

11,3

6,8

4,5

4,5

11,3

4,5

15,9

2,2

2,2

$-$

9

11,3

When we evaluate findings in Table 2, most of the students have stated before the application that they are individuals sensitive to environment and they show this sensitivity by keeping the environment clean, planting trees, not damaging the environment, warning people, recycling. The students have stated also what they've done is not enough for a sustainable environment. Participant 26 has emphasized that she/he is sensitive but it is not 
enough for a sustainable environment because we don't have an environmental consciousness as society by using the statement "I think I'm sensitive. I try to keep clean the environment and not damage any animals. No, because we don't have this consciousness as society, and this makes me very sad". And Participant 6 has stated that her/his own efforts were not enough for a sustainable environment by using the statement "Yes because I don't leave my rubbish in nature and I put the rubbishes into dustbins wherever I see. I feed the animals. No, it is not enough because many people pollute the nature as much as I make efforts". Some participants have emphasized that they show their environmental sensitivity by doing certain activities like warning people, feeding the animals, recycling as well as keeping the environment clean but what they've done are not enough for a sustainable environment. In this regard, Participant 37 used this statement: "Yes, I think. First, I keep the environment clean, I make contribution to energy saving and I warn those who do not pay attention in this respect. However, what I've done is not enough; other people should take these responsibilities too". And some participants have emphasized that they are sensitive to environment and what they've done are enough for a sustainable environment. In this regard, Participant 11 has stated what she/he has done is enough for a sustainable environment by using the statement " $I$ think I'm sensitive to environment. I don't throw rubbish in order to show my sensitivity, I pick up the rubbish and then put it into the dustbin, I don't waste the energies, etc. To me, these are enough to create a sustainable environment".

When evaluating the finding $\mathrm{s}$ in Table 2, a great majority of the students have stated after the application that they are sensitive to environment. Some students have expressed that they had actually no sensitivity before the application but their sensitivity increased after the project and they understood they had damaged the world more. Students have stated that they show their environmental sensitivity by keeping the environment clean, protecting the environment and warning people just as before the application. Some students have stated they understood by this project that they should do more for the environment. The students have also stated what they've done for environment are not enough for a sustainable environment and everybody else should make struggle for environment. In this regard, Participant 18 has stated she/he has become more sensitive compared to pre- project by using the statement "I was not really sensitive before the project. I've been afraid of what were told in the project and what might happen in the future. After this, I will let people use oils 3 times and then I will take them to school or municipality. I will collect the covers, and I will put the paper, plastic, recyclable wastes into recycling bins". Similarly, Participant 37 has emphasized that she/he has become more sensitive after the project but being sensitive alone is not enough by using the statement "I've become a more sensitive to the environment after this study. I showed a love for animals where we went, I didn't damage any plants, I picked up the rubbish. But unfortunately it is not enough only we do so". Some participants have emphasized that they thought they were sensitive before the project and protected the environment enough but they've understood after the project that they were not actually sensitive enough. In this regard, Participant 43 has expressed he/she understood after the project that actions he/she took are not enough by using the statement "I said yes for this question before starting the project. But after this project I've realized that what I did are not really enough. So I think that I've started to make progress in the course of being sensitive but this progress will never stop. "After the project, some students have emphasized they will warn people around them more about environment because being sensitive alone is not enough for a sustainable environment. In this regard, Participant 19 has expressed that "I will try to warn angrily those who damage the environment but a sustainable environment is not possible only with me. But as I've learned, only my benefits may even save several things".

\section{Environmental Consciousness of Gifted Students}

In the study, "Do you think you are an individual with environmental consciousness? What is your attitude to living and lifeless components creating the ecosystem with this consciousness?" questions are addressed to the students in order to determine environmental consciousness of the students before and after the application. Table 3 includes findings obtained by answers from the students. 
Table 3. Opinions of Gifted Students on Environmental Consciousness

\begin{tabular}{|c|c|c|}
\hline \multirow[t]{2}{*}{ Category } & \multicolumn{2}{|c|}{ Percentage distribution } \\
\hline & Pre-application & Post-application \\
\hline I think I've environmental consciousness & 95,4 & 88,6 \\
\hline $\begin{array}{l}\text { I protect living and lifeless creatures in } \\
\text { environment }\end{array}$ & 50 & 68,1 \\
\hline I'm kind to living and lifeless creatures & 40,9 & - \\
\hline I warn people & 13,6 & - \\
\hline $\begin{array}{l}\text { I think I've partially environmental } \\
\text { consciousness }\end{array}$ & 6,8 & - \\
\hline $\begin{array}{l}\text { I don't think I've environmental } \\
\text { consciousness }\end{array}$ & 2,2 & - \\
\hline $\begin{array}{l}\text { I will protect living and lifeless creatures } \\
\text { more }\end{array}$ & - & 43,1 \\
\hline $\begin{array}{l}\text { My environmental consciousness has } \\
\text { developed after the project }\end{array}$ & - & 22,7 \\
\hline I'll warn people more & - & 9 \\
\hline
\end{tabular}

When evaluating the findings in Table 3, most of the gifted students have expressed before the application that they had environmental consciousness. Most of the students have stated that they protect the environment, living and lifeless creatures and are kind to them but only $12 \%$ of them warn other people about the environment. In this regard, Participant 4 has emphasized that he/she has environmental consciousness, protect the components creating the ecosystem and do not damage them by using the statement "Yes I think. I know each living creature represents a circle in the ecosystem and every single circle is important. So I don't use products harmful to the nature and I don't damage habitats of animals". Participant 11 has emphasized that he/she warns people who damage the environment by using the statement "I've environmental consciousness. I warn people who hunt too much, don't throw rubbish into sea and pick up the rubbish in the sea for the creatures living in the sea". Participant 34 has emphasized that any damage to a smallest living creature in the ecosystem would affect other living creatures through food chain by using the statement "Yes, I don't want to damage any living creatures creating the ecosystem because even a smallest living creature can damage all other living creatures through food chain." Some participants have stated they've not enough environmental consciousness. In this regard, Participant 3 has expressed that he/she can damage living and lifeless entities by using the statement "No, I don't think. The reason is people may be sometimes insensitive and might damage living and lifeless creatures unavoidably." Similarly, Participant 19 has emphasized that he/she had no environmental consciousness but he/she made enough effort to protect the environment by using the statement "I've less environmental consciousness but I'm economic as much as I can".

When we evaluate findings in Table 3, a great majority of the students indicated they had environmental consciousness after the project; but there is a decrease in comparison to the percentage involved in pre-test. This decrease indicates that while students thought they had environmental consciousness at the beginning of project, they then changed their minds after getting training on environmental consciousness and realized that in fact they were not exactly conscious. In this regard, Participant 36 has expressed that information she/he learned during the project period have developed his/her environmental consciousness by using the statement "After this project I think I'm an individual with environmental consciousness. The reason is dear teachers have taught us everything blow-by-blow ranging from role of creatures living in nature in the ecosystem to their extinctions". Similarly, Participant 5 has emphasized that she/he will show better attitudes to the environment by using the statement "Yes, I will show better attitudes now compared to the past". Participant 19 has used the statement "After this project I don't think I have environmental consciousness. I will show a polite, kind attitude to the ecosystem and try to not damage". Participant 28 has emphasized that the project develops the environmental consciousness and he/she will be more careful to protect living and lifeless creatures by using the statement "Yes, I think. In fact, I believe 
the project completes my uncompleted conscious. I will try to not damage living and lifeless components creating the ecosystem and not disturb natural balance". Similarly, Participant 34 has used the statement "After this project I think I have environmental consciousness. I will try to not disturb any living and lifeless creatures as I've learned they all live in a harmony in the nature".

\section{Environmental Awareness of Gifted Students}

In the study, "Do you have awareness of environment? Can you evaluate with the reasons what is the level of your environmental awareness?" questions are addressed to the students in order to determine environmental awareness of the students before and after the application. Table 4 includes findings obtained by answers from the students.

Table 4. Opinions of Gifted Students on Environmental Awareness

\begin{tabular}{|c|c|c|}
\hline \multicolumn{3}{|c|}{ Percentage distribution } \\
\hline Statements & Pre-application & Post-application \\
\hline I have awareness of environment & 88,6 & 88,6 \\
\hline At medium level & 4,5 & 18,1 \\
\hline I care about environment and living creatures & 18,1 & - \\
\hline I keep environment clean & 13,6 & 15,9 \\
\hline $\begin{array}{l}\text { I have limited information on environment and } \\
\text { living creatures }\end{array}$ & 13,6 & - \\
\hline Ay high level & 11,3 & 20,4 \\
\hline I have no awareness of environment & 9 & 2,2 \\
\hline I don't damage the environment & 6,8 & -- \\
\hline I inform people on environment & 4,5 & - \\
\hline I don't take enough action on environment & 4,5 & - \\
\hline My awareness is increasingly developing & 2,2 & 4,5 \\
\hline I sometimes throw rubbish in nature & 2,2 & - \\
\hline There is no place to plant trees & 2,2 & - \\
\hline I plant trees & 2,2 & - \\
\hline I react when people damage the nature & 2,2 & - \\
\hline My awareness has developed by the project & - & 40,9 \\
\hline I protect the environment & - & 22,7 \\
\hline I know about environment & - & 20,4 \\
\hline I know how I treat environment & - & 11,3 \\
\hline I know how I affect nature & - & 11,3 \\
\hline I recycle & - & 6,8 \\
\hline
\end{tabular}

When we evaluate findings in Table 4, most of the students have indicated they had environmental awareness. Participants who indicated they had high level of environmental awareness have expressed they care about environment and warn those who damage the environment. In this regard, Participant 22 has expressed that he/she has high level of awareness but it can be better by using the statement "I think I have a good level of environmental awareness. But yet I should have higher level of awareness". Participant 26 has emphasized that his/her 514 
environmental awareness is high and he cares about animals by using the statement "I think I have awareness. My environmental awareness is quite high because I care about living creatures and animals too much". As for participants whose environmental awareness is at medium level, they have emphasized they took care of environment and their knowledge of environment was limited. In this regard, Participant 15 has emphasized that his/her awareness level is not too much and they have lack of knowledge by using the statement "I love environment but my awareness level is not too much. I don't know well about things about global warming". Participant 29 has expressed that there are much more to do apart from being aware of importance of the environment and not damaging the environment by using the statement 'I'm aware of environment. But I don't think my awareness level is high. In that, I only know importance of environment and do not damage it. But there might be something to do for environment apart from these". Some participants have indicated they have no environmental awareness. In this regard, Participant 14 has stated "I have no awareness of environment." while Participant 23 has stated "In fact, I'm not. If other people care about environment, it is normal because my love of nature is not extreme".

When we evaluate findings in Table 4, again most of the students have stated after the application that they had environmental awareness. Almost 50\% of the students have expressed that their environmental awareness developed during the project period. In this regard, Participant 7 has stated that his/her environmental awareness increased by the environmental education by using the statement "Yes, I know it. While it was almost zero before this environmental education of sufficient level, it is better now". Similarly, Participant 18 has emphasized that what she/he learned during the project have increased her/his environmental awareness by using the statement " $M y$ awareness has increased much more after the project. The reason is resources might run out, we might leave a bad future for our children, grandkids. So we should use them carefully". It is determined in the study that awareness level of some students has increased after the application compared to pre- application. In this regard, Participant 22 has stated "My awareness level was good. But my awareness has increased thanks to the project". Similarly, Participant 39 has expressed that his/her awareness level has increased compared to pre-project by using the statement "I have $85 \%$ of environmental awareness which this figure was $60 \%$ before participating this project. After the project, I understood that all small steps gather and they become huge steps naturally and I saw negative results of saying "what can one person do" and my awareness increased". It is determined in the study that students have more information on environment after the project and so environmental awareness has increased. In this regard, Participant 19 has stated that increase in knowledge level will raise the awareness by using the statement "While I'm at the medium level previously, I'm at a good level now. In that, I've learned what I don't know". Similarly, Participant 29 has emphasized that information got on environment during the project has increased his environmental awareness by using the statement "I have awareness of environment. But I thought previously that my awareness was less. But I think my awareness has increased after the project of Explorers in Nature. The reason is I 've gotten information on environment by having fun".

\section{Ecological Responsibilities of Gifted Students}

In the study, students are asked to complete statement "I'm a responsible individual for ecology because .." in order to determine ecological responsibilities of the students before and after the application. Table 5 includes findings obtained by answers from the students. 
Table 5. Opinions of Gifted Students on Ecological Responsibilities

\begin{tabular}{lcc}
\hline Category & Percentage distribution & \\
\hline & Pre-application & Post-application \\
\hline I protect the environment & 13,6 & 18,1 \\
I keep the environment clean & 13,6 & 6,8 \\
Environment is our source of life & 9 & 31,8 \\
I don't damage the environment & 9 & - \\
Nature is out future & 9 & 9 \\
Environment doesn't belong only us & 9 & 9 \\
I know results of environmental pollution & 6,8 & - \\
I'm part of environment & 6,8 & - \\
Environment creates our ecosystem & 4,5 & - \\
I live depending on environment & 4,5 & - \\
Our environment is important & 2,2 & - \\
We interact with environment & 2,2 & - \\
I know how should I treat environment & 2,2 & 91,3 \\
We need environment & - & 9 \\
There is something to do for environment & - & 9 \\
I care about environment & - & 9 \\
Environment is our & - & 4,5 \\
We're trusted with environment & - & 2,2 \\
I saw the importance of environment & - & - \\
I raise awareness of people & - & - \\
I have environmental consciousness & -2 & - \\
\hline
\end{tabular}

When evaluating the findings in Table 5, a great majority of students have stated they are individuals who have responsibilities for environment. Students explained their responsibilities for the environment by some reasons like keeping the environment clean, protecting and not damaging the environment, being a part of environment and environment is their source of life. Besides, they have indicated they are not alone in the environment. In this regard, Participant 8 has expressed he/she interacts with the environment and so he/she has an ecological responsibility by using the statement "I'm an individual having ecological responsibilities for the environment because what happens around me will affect me and my actions affect my environment". Participant 39 has emphasized that damages to the environment will affect us sooner or later so we bear ecological responsibility by using the statement "We are a part of this environment too. If we don't fulfill our responsibilities for the environment, then it will damage us sooner or later. In that, we are a circle creating the ecosystem too. If we don't want to destroy our own circle, then we should not destroy our environment (other circles) as well". Participant 3 has emphasized that we are not alone in the World and we bear ecological responsibility as we should protect other living creatures by using the statement "There is not only people in the world. There are too many living creatures excluding people. We should protect other living creatures too".

When we evaluate findings in Table 5, all students have indicated after the application that they bear ecological responsibilities. It is determined students build their ecological responsibilities on certain reasons such like 
regarding environment as habitat, protecting the environment, need for environment, caring about environment, being not alone in nature, environment is the future and keeping the environment clean. It is determined that reasons on which students build their ecological responsibilities vary and students emphasize on that environment is habitat and there is a need for environment. In this regard, Participant 9 has emphasized that the reason why he/she bears ecological responsibility is environment is our habitat by using the statement "Environment is our home and we should protect it". Participant 12 has emphasized that the reason why he/she bears ecological responsibility is environment is our future by using the statement "Environment means our future. In that, we should not destroy our future by destroying our environment". Participant 26 has stated that the reason why he/she bears ecological responsibility is environment is our future by using the statement "Environment means our future. In that, we should not destroy our future by destroying our environment". The reason why he/she bears ecological responsibility is environment is our future by using the statement "Environment means our future. In that, we should not destroy our future by destroying our environment". The reason why he/she bears ecological responsibility is environment is our future by using the statement "Environment means our future. In that, we should not destroy our future by destroying our environment". The reason why he/she bears ecological responsibility is environment is our future by using the statement "Environment means our future. In that, we should not destroy our future by destroying our environment". The reason why he/she bears ecological responsibility is environment is our future by using the statement "Environment means our future. In that, we should not destroy our future by destroying our environment". The reason why he/she bears ecological responsibility is environment is our future by using the statement "Environment means our future. In that, we should not destroy our future by destroying our environment". The reason why we have ecological responsibility is people are not the only owners of environment by using the statement "I'm conscious. I know environment doesn't belong to only us and we risk safety of all other creatures when we damage the environment. "Some participants have expressed what they've learned in the project would help them to bear ecological responsibility. In this regard, Participant 15 have established a relation between bearing an ecological responsibility and what they learned in the project by using the statement "I've learned how much the environment is important and to what extent each part of environment is necessary".

\section{Opinions of Gifted Students on Environmental Education}

In the study, "Do you think environmental education is necessary? Why?", "If you define environmental education by an expression of you such like difficult, easy, enjoyable, boring..., what will this definition be?" questions are addressed to the students in order to determine opinions of the students on environmental education before and after the application. Table 6 includes findings obtained by answers from the students.

Table 6. Opinions of Gifted Students on Environmental Education

\begin{tabular}{lcc}
\hline Category & Percentage distribution \\
\hline Environmental education is required & Pre-application & Post-application \\
Environmental educations are enjoyable & 95,4 & 97,7 \\
To develop an environmental consciousness & 63,6 & 75 \\
To protect the environment & 18,1 & 36,3 \\
To know the environment & 18,1 & 15,9 \\
To develop an awareness of environment & 15,9 & 6,8 \\
Environmental educations are boring & 11,3 & - \\
Environmental educations are enjoyable & 11,3 & 4,5 \\
Environmental educations are educational & 9 & - \\
To keep our environment clean & 9 & 9,6
\end{tabular}


Environmental educations are difficult

To make our environment more beautiful

Environment is our source of life

We should learn about environment by experiencing

So that people understand importance of the environment

To develop environmental awareness

I've understood importance of environmental education by the project

Environmental educations are interesting

To get information on the environment

Environmental educations are difficult

People should know effects of their behaviors on the environment

Make us respect to environment
9

4,5

4,5

4,5

2,2

4,5

2,2

11,3

9

9

9

6,8

4,5

When we evaluate the findings in Table 6, students have stated that environmental education is required to know about environment, protect environment, keep the environment clean and develop environmental consciousness and sensitivity. While most of the students indicate environmental educations are enjoyable, there are some students who indicate environmental educations are boring, difficult, enjoyable, educational, intriguing, exciting and interesting. In this regard, Participant 16 has emphasized that each individual would understand importance of environment with the environmental education by using the statement "Yes, it is required. The reason is each individual should learn importance and necessity to keep the environment clean". Participant 19 has emphasized that environmental education is required for environmental consciousness by using the statement "I think it is necessary. In that, we damage excessively the environment now due to some unconscious people". Participant 33 has emphasized that environmental education should be compulsory since the environment is our habitat by using the statement "I think this education is required to be compulsory for everybody. Since the ambient giving us life is our environment. We get our food, drinks, air here." Participant 39 has emphasized environmental education is required to bring an environmental consciousness at early ages by using the statement "Yes, the reason is that individual whose environmental conscious didn't raise and who have no respect to animals, plants, environment have no respect either society or himself. Thus, value of environmental consciousness should be being in child at earl ages."

When we evaluate findings in Table 6, all students have stated after the application just as before the application that environmental education is necessary. Students have emphasized that environmental education is required to develop environmental consciousness, protect the environment, keep the environment clean, get information on environment and know about environment. There is an increase in number of students who indicate environmental educations are enjoyable, educational, interesting compared to the pre-application. In addition, there is a decrease in number of students who consider environmental educations as difficult. When considering the opinions of participants, Participant 11 has expressed that environmental education is required for a livable World by using the statement "I think it is necessary. If people don't get education or they don't become conscious on this subject, future of our planet is not good." Participant 5 has emphasized that environmental educations will offer a chance to be responsible for the environment by using the statement "For sure. In that, this world is ours and we all should be responsible for the World. Otherwise, it will be end of the world. "Some participants have indicated in the study that they realized how the environmental education is important through the environmental education involved in the project. Participant 19 has expressed that he/she would protect the environment much more through that environmental education by using the statement "It is highly necessary because, for example, we try to protect environment more after getting environmental education". 


\section{Meeting the Expectations of Gifted Students from Environmental Education Project}

In the study, "What did activities bring you within the scope of "Explorers in the Nature" Project?" question is addressed to the students in order to determine whether expectations of students from environmental education project are met after the application. Table 7 includes findings obtained by answers from the students.

Table 7. Opinions of Gifted Students on Environmental Education Project

\begin{tabular}{lc}
\hline Statements & Post application (percentage) \\
\hline It provided an environmental consciousness & 29,5 \\
It gave information on nature & 29,5 \\
I learned about ecosystem & 25 \\
I learned my ecological footprint & 15,9 \\
It encouraged to protect environment & 15,9 \\
I learned plants & 13,6 \\
It taught me my responsibilities for environment & 9 \\
It changed my perspective of environment & 9 \\
I learned different ecosystem & 9 \\
I learned fossils & 9 \\
I learned my carbon footprint & 9 \\
I learned animal types & 9 \\
It gave me love of nature & 9 \\
Lives of silkworms & 6,8 \\
It brought environmental sensitivity & 6,8 \\
It increased environmental awareness & 6,8 \\
It learned importance of environment & 6,8 \\
I learned acid rains & 6,8 \\
Relation between different disciplines and nature & 4,5 \\
It allowed me to explore the nature & 2,2 \\
It brought joy of life and hope & 2,2 \\
\hline
\end{tabular}

When we evaluate findings in Table 7, students have indicated that their expectations from the environmental education project were met after the application. Students have indicated that they got information on environment and ecosystem, environmental consciousness, environmental sensitivity and awareness in the environmental education project in question. Besides, students have indicated that project encourage them to protect the environment, give a love of nature and teach their responsibilities for the environment. In this direction, Participant 5 has emphasized that project brought in an environmental consciousness by using the statement "It brought me in a good consciousness of nature after my own heart." Participant 42 has emphasized the project raise the environmental consciousness, give information and teach their responsibilities by using the statement "It raised my consciousness of environment. It told how to carry out group working with different group activities. It transferred highly important and useful information about ecosystem. It raised my individual responsibility with silkworms. It increased my interrogation. It taught correct things instead of misinformation I knew." Participant 12 and Participant 37 have emphasized that project brings in different perspectives on the environment respectively 
by using the statement "Project has brought me what I expected. My perspective on environment and all creatures has changed" and the statement "I've regarded the nature more different compared to the past. I performed something I've never tried. I get information I've never learned. "Participant 39 has indicated that every small contribution to environment is very important by using the statement "Project has changed my perspective on life and environment. We should know there is no need for big projects to contribute and help the environment and even small contributions affect our environment". Participant 9 has emphasized that project give several information in an entertaining and practical way by using the statement "It introduced me with nature. It has made me closer to the nature. It has taught us ecosystem and other concepts in an enjoyable and practical way. "

\section{Discussion and Conclusion}

Effect of nature education, which was continued for six days with the activities prepared by academicians and teachers within the scope of project called TÜBITAK 4004 "Science and Art Explorers are in Nature", on environmental awareness and sensitivity of gifted students has been examined in this study. Data was collected by the surveys applied before and after the educations and descriptive analysis was performed. It was determined based on the findings that gifted students thought that they were sensitive to the environment and showed positive attitudes before and after the application. It was determined in the previous studies that attitudes of gifted students to the environment were positive (Esen, 2011; Aydın, Coşkun, Kaya and Erdönmez, 2011; Bakar and Aydınlı, 2012; Uğulu, Akkaya \& Erkol, 201) and even their positive attitudes and sensitivity are significantly different from their peers with normal intelligence levels (Uğulu, 2013; Sontay, Gökdere \&Usta, 2014; 2016). When considering research findings, after the education there is a decrease in number of individuals who thought they were sensitive to environment since it is reached at the result of trainings within the scope of project that individuals thought they were sensitive to the environment at the beginning of the project but they have realized through their awareness and sensitivity increased by the educations that they must have made much more efforts to protect environment and develop sensitivity. For example, there is a decrease more than $20 \%$ in the number of students who expressed before the applications that they kept the environment clean and what they did were enough for a sustainable environment. The obtained results have demonstrated that students' environmental awareness, sensitivity and consciousness developed by the educations within the project, they have started to protect environment more and pay attention to recycle and turn it into a behavior. Primary purpose of an effective environmental education is to form environmental behaviors of individuals in a positive sense and change in attitudes is important in behavioral change (Bradley, Waliczek\&Zajicek, 1999). When gifted students have much more information on environment, environmental issues and solution for them, they think at high level to prevent and solve these problems and they might become a decision-maker by developing much more sensitivity (Winocur and Maurer, 1991; Clark, 1992; Esen, 2011). It was observed in the current study that gifted students have given more conscious answers to the questions about environment and they have started to turn their information into behaviors and therefore their environmental sensitivity have increased after the academicians and teachers gave education on the issues such like acknowledgment, protection, sustainability of nature, environmental issues and solutions, etc. which took six days. At this point, it can be stated that environmental educations provided within the scope of project have created positive effects on attitudes and behaviors of students to the environment.

Furthermore, activities within the scope of project were not limited to the class environments in science and art center and field tours were conducted in some places such like Istanbul University classrooms and Botanical Garden, Belgrad Forest and Atatürk Arboretum where students could observe directly and experience the nature and the things it contains. In the study, it is found in direction of answers obtained from the students that students have indicated that they have fun and learn in learning environments excluding the schools and learn more effectively. While Sebasto and Cavern (2006) state students learn by having fun in the outdoor activities in environmental education, Dienno and Hilton (2005) state that field tours conducted in the environmental education have important effect on developing positive attitudes to the environment. In this context, we can say out-of-class activities within the scope of project trainings are effective in development of environmental sensitivity and awareness; generally positive attitudes to the environment. As another reason why students learn by having fun in the project educational period, it can be indicated as the study is not prepared based on an educational sense concentrated only students to get theoretical information on environment. Since in this educational period the students drew environment-themed pictures, designed several objects with the materials in nature, listened to the nature in order to realize creatures living in the forest, followed how caterpillar become a butterfly in order to realize formation of a living creature, calculated his own carbon footprints, designed plays by the materials they 
found in nature and conducted many similar activities. Again we can say these works may be effective in the answers of students in which they expressed they had learned by having fun.

In the light of what mentioned above, it is possible that gifted students who have naturally sensitivity to environment and protection of environment by their characters might gain more awareness and sensitivity, have more positive attitudes and offer creative solutions to the current events by getting an environmental education. It can be thus suggested to conduct longer educations through similar activities, especially out-of-class learning environments in order to get effective results.

\section{Acknowledgements}

We would like to thanks to TÜBİTAK for their contributions to the study with project number $117 \mathrm{~B} 072$ 


\section{Özel Yetenekli Öğrencilerin Çevre Farkındalık ve Duyarlılıkları: "Bilim ve Sanat Kâşifleri Doğada"}

\section{Giriş}

Çevre sorunları, günümüzün en temel problemlerinden biri haline gelmiştir. Soluduğumuz havadan içtiğimiz suya kadar, orman yangınlarından toprak kirliliğine kadar çevre ile ilgili pek çok konu günlük yaşamımızın önemli gündemi haline gelmiştir. Çevre sorunlarının üstesinden gelebilmek için çeşitli yasal ve teknolojik tedbirler alınmış olsa da çevre sorunları sadece teknoloji ile veya yasalarla çözülebilecek bir sorun değildir (Erten, 2003). Çevre sorunlarının çözümünde anahtar kavram toplumu oluşturan bireylerin eğitimi olarak yansımaktadır. Çevre konusunda harekete geçmenin ön koşulu çevre sorunlarının farkında olmaktır. Dolayısıyla küresel ölçekte çevresel bozulmaya karşı savaşmanın en önemli bileşeni, hem formal hem de informal anlamda etkili bir çevre eğitimi olarak görünmektedir (Taylor \& diğ., 2009).

Zeleny ve Schultz (2000)'a göre bireysel sorumluluklar ve davranış değişikliği çevre krizlerinin çözülmesi için en önemli unsurdur. Davranışların istendik yönde değişimi ise halkın eğitilmesini gerektirir. Ailede başlayan çevre eğitimi okullarda ve yaşanılan toplumda devam eder. Önemli olan çocukların doğayla buluşmasını ve erken yaşlardan başlayarak doğa sevgisi kazanmasını sağlamaktır (Birinci, 2007). İnsanın en hızlı öğrenme ve öğrendiklerini davranışa yansıtabilme çağında, öncelikle uygulamalı eğitime ağırlık verilmeli, öğrencilerin yaparak, hissederek, yaşayarak öğrenmeleri sağlanmalıdır (Sarıkaya, 2007).

Doğanın Korunması için Uluslararası Birlik (International Union for Conservation of Nature-IUCN) ein 1970 yılında Nevada'da düzenlediği “Okul Programlarında Çevre Eğitimi” adlı konferansın çevre eğitiminin gelişmesine büyük katkısı olmuştur. Bu konferansta "çevre eğitimi” "insanlar, kültürler ve biyofiziksel çevre arasındaki ilişkiyi kavramak, gerekli tutum ve becerileri geliştirmek için kavramların açıklanması ve değerlerin fark edilmesi süreci” (IUCN, 1970) olarak tanımlanmış ve bu tanım pek çok ülkede pek çok kuruluş tarafından kabul edilmiştir (Neal \& Palmer, 1994). Çevre eğitimi ile ihtiyacı kadar tüketen, gelecek nesillerin sorumluluğunu almış, çevre sorunlarına karşı duyarlılık ve bilinç sahibi, olumlu ve kalıcı davranış değişiklikleri kazanmış, sorunların çözümünde aktif katılım sağlayan (Şimşekli, 2004), çevre ile ilgili uygun karar verebilen ve doğru davranışları gösterebilen (Hart, 2007) bireylerin yetiştirilmesi amaçlanmaktadır. Toplumda çevre bilincinin ve duyarlılığının oluşması, dikkat çekici çalışmalar yapılması açısından bu rollerde liderlik yapacak ve sorumluluk alabilecek bireylere ihtiyaç duyulmaktadır. Bu noktada özel yetenekli öğrenciler, özellikle küresel sorunlara yönelik sahip olduğu yoğun hassasiyet (Piechowski, 1997) ve üst düzey problem çözme ve üretme becerileri sebebi ile doğa ve canlılar ile ilgili sorunlara çözümler bulma noktasında teşvik edilmesi gereken kaynaklar olarak görülmektedirler (Mönks, Heller \& Passow, 2002). Çünkü özel yetenekli öğrencilerin, merak duygularını ve hayal güçlerini harekete geçirdiği için doğal çevreye yönelik doğuştan ilgileri vardır (Smutny \& Von Fremd, 2004) ve çevrede meydana gelen olumsuz değişimlere ilgi gösterirler (Lovecky, 1993). Ayrıca doğal çevreye zarar veren durumların ortaya koyularak, neden korunması gerektiğinin düşünülmesi noktasında iyi bir muhakeme becerisi olması gerekir ki özel yetenekli öğrencilerin muhakeme becerileri oldukça gelişmiştir (Sisk, 2007). Bu yüzden özel yetenekli öğrenciler birçok küresel problemlerle karşılaşırken, bu problemlere yönelik çözüm bulma potansiyeline de sahiptirler (Çağlar, 1972).

Çevre eğitimi disiplinler arası bir çalışma alanıdır. Hem bilişsel, hem de duyuşsal alanda amaçları vardır. Bilişsel alandaki amaçları, kişileri daha çevre okuryazarı yapmaya yönelirken, duyuşsal alandaki amaçları çevreye ve çevre sorunlarına karşı değer ve tutumları oluşturur (Budak, 2008). Bunun yanında çevreye yönelik bireysel davranışların değişmesi ile çevre konularına yönelik tutum, bilgi ve değer yargılarının da olumlu yönde değişmesi mümkün olur (Erten, 2005). Özel yetenekli öğrenciler doğa ve fen ile ilgili çok farklı gerçekleri bilirler, bilimsel açıdan öğrendikleri kavramları derinlikle anlarlar (Gould, Weeks \& Evans, 2003) ve spesifik örneklerden öğrendiklerini daha genel örneklere transfer etme noktasında bir iç görü ve anlayışa sahiptirler (Kopelman, Galasso \& Strom, 1977; Ngoi ve Vodracek, 2004). Bu bilgileri, etraflarını yakından gözlemleyerek (Karnes \& Riley, 2005), başkalarının kaçırdığı problemleri fark edip, tanımlayarak (Meador, 2003) ve açık uçlu problem durumlarının araştırılmasından zevk alarak elde ederler. Bu yüzden içinde yaşadıkları çevreye karşı daha hassas ve bu çevrede yaşanan problemleri fark etme ve çözüm üretme noktasında yaşıtlarına göre daha hassas ve etkindirler. Doğaya ve çevreye gösterdikleri hassasiyet ve yaşanılan sorunlara çözüm bulma istekleri sebebiyle bu noktada gerçekten sorumluluk alabilecek kişiler oldukları düşünüldüğünde, bu öğrencilerin çevreye yönelik farkındalık ve duyarlılıklarının ne düzeyde olduğu önem arz etmektedir. Bu bağlamda ülkemizde özel yetenekli öğrencilerle çevreye yönelik bazı nicel çalışmalar yapılmıştır.

Esen (2011) özel yetenekli öğrencilerin çevre bilgilerinin ve çevreye yönelik tutumlarının cinsiyet, sınıf düzeyi ve sosyo-ekonomik düzeye göre incelenmesi üzerine çalışırken; Aydın, Coşkun, Kaya ve Erdönmez (2011) de benzer bir şekilde özel yetenekli öğrencilerin çevreye yönelik tutumlarının cinsiyet, sınıf düzeyi vb. değişkenler açısından incelenmesi üzerine çalışmıştır. Bakar ve Aydınlı (2012), özel yetenekli öğrencilerin plastik atıkların 
geri dönüşümü ve çevreye etkileri konusundaki tutumlarını cinsiyet, sınıf değişkeni vb. gibi değişkenler açısından incelerken; Uğulu, Akkaya ve Erkol (2013) yine özel yetenekli öğrencilerin çevreye yönelik tutumlarının cinsiyet, yaş ve sınıf değişkenleri açısından incelemişlerdir. Diğer çalışmalardan farklı olarak Uğulu (2013) ve Sontay, Gökdere ve Usta (2014; 2016), özel yetenekli öğrenciler ile normal zihin düzeyindeki akranlarını çevreye yönelik tutumları, çevre okuryazarlık bileşenleri ve çevresel davranış özellikleri açısından karşılaştırmaya yönelik çalışmalar yapmışlardır. Görüldüğü üzere daha önce yapılan bu çalışmalar genel olarak iki farklı şekilde yürütülmüştür. Bazı çalışmalar özel yetenekli öğrencilerin çevreye yönelik tutum, çevreye yönelik bilgi vb. gibi değişkenleri cinsiyet, sınıf düzeyi, sosyo-ekonomik düzey vb. gibi demografik özellikler açısından inceleyen nicel çalışmalar olurken; bir grup çalışma ise özel yetenekli öğrenciler ile normal zihin düzeyinde yer alan öğrencilerin çevreye yönelik tutum, çevre okur-yazarlık durumları, çevre davranışları vb. gibi değişkenlerin karşılaştırılmasını incelemiştir. Fakat özel yetenekli öğrencilerin var olan çevreye yönelik farkındalıklarının ve duyarlılıklarının artırılarak daha etkin hale getirilmesi hakkında çalışmalara rastlanılamamıştır. Oysa Winocur ve Maurer (1991) özel yetenekli öğrencilerin çevre, çevrenin korunumu, çevre problemler vb. konularla ilgili verilen eğitimler sayesinde üst düzey düşünme becerilerinin gelişeceğini ve öğrencilerin küresel konulardaki ilgilerinin artabileceğini belirtmiştir. Özel yetenekli bireyler daha fazla bilgi edindikleri takdirde, karşı karşıya olduğumuz küresel çevre sorunlarıyla ilgili daha çok kaygı duyup, hassasiyet geliştirmekte ve çözüme yönelik ilgi oluşturmaktadır (Clark, 1992). Bu yüzden özel yetenekli öğrenciler çevreye yönelik doğru eğitim aldıklarında, çevreyle ilgili önemli kararların alınmasında ya da çevreye yönelik uygulamalarda çevrenin koruyucu kalkanları olabileceklerdir (Esen, 2011). Bu bağlamda mevcut çalışmanın amacı özel yetenekli öğrencilere proje kapsamında verilen çevre eğitiminin, öğrencilerin çevreye yönelik farkındalık ve duyarlılıklarında bir değişiklik oluşturup oluşturmadığını ortaya koymak; etkililiğini incelemektir. Alan yazın incelendiğinde bireylerin çevreye yönelik farkındalık ve duyarlıklarının belirlendiği çalışmaların büyük oranda nicel araştırma yöntemlerine dayalı oldukları görülmektedir. Ayrıca nitel olarak yürütülecek olan mevcut çalışmanın çevre ve çevre sorunlarına yönelik eğitimlerin özel yetenekli öğrencilerin çevreye yönelik farkındalıklarına, çevre duyarlıklarına, çevre tutumlarına etkileri olup olmadığı yönündeki çalışmalara katkı sağlayacağı düşünülmektedir.

\section{Yöntem}

Araştırmada nitel araştırma yöntemlerinden durum çalışması deseni kullanılmıştır. Çalışmada özel yetenekli ögrencilerin çevre farkındalık ve duyarlılık düzeylerinin ne yönde olduğu ve uygulanan çevre eğitimi projesiyle nasıl değiştiği incelenmiştir. Araştırmada, özel yetenekli öğrencilerin çevre farkındalık ve duyarlılıklarını geliştirmek amacıyla "Bilim ve Sanat Kâşifleri Doğada" isimli TÜBİTAK projesi gerçekleştirilmiştir. Proje kapsamında akademisyenler ve öğretmenler tarafından geliştirilen etkinliklerle İstanbul Üniversitesi, Bahçelievler Bilim ve Sanat Merkezi ve Belgrad Ormanında altı gün süren eğitim gerçekleştirilmiştir. Araştırma sürecinde özel yetenekli öğrencilerin fiziğin, kimyanın, biyolojinin ve matematiğin doğadaki yerini ve sanata ilham kaynağı olan doğal güzelliklerini fark etmelerini sağlayacak, çevreye yönelik farkındalık ve duyarlılıklarını geliştirecek uygulamalı etkinlikler yapılmıştır. Veri toplama aracı olarak geliştirilen anketler eğitimden önce ön test, uygulamadan sonra ise son test olarak öğrencilere uygulanmıştır.

\section{Çalışma Grubu}

Araştırmaya İstanbul ilinden 40, Aydın ve Tekirdağ illerinden 5'er öğrenci olmak üzere toplam 50 özel yetenekli ögrenci katılmıştır. Öğrencilerin seçiminde ölçüt örneklem yöntemi kullanılmıştır. Ölçüt olarak özel yetenekli olarak tanılanmış olmak, cinsiyet, projeye başvuru yapmak, yedinci sınıfı tamamlamış olmak göz önünde bulundurulmuştur. Katılımcıların tamamı Milli Eğitim Bakanlığına bağlı Rehberlik Araştırma Merkezleri tarafından özel yetenekli olarak tanılanmış öğrencilerden seçilmiştir. Katılımcıların 25'i erkek, 25'i kız öğrencilerden oluşmaktadır. Araştırma sürecinde devamsızlık, ön ve son uygulamaya katılmama nedeniyle 6 öğrencinin verdiği cevaplar analiz kısmına dâhil edilmemiştir.

\section{Veri Toplama ve Analiz Yöntemleri}

Veri toplama aracı olarak öğrencilerin çevre farkındalık ve duyarlıklarını belirlemek amacıyla yedişer açık uçlu sorudan oluşan iki anket kullanılmıştır. Araştırmacılar tarafından geliştirilen anket, Fen Bilimleri Eğitimi ve Özel Yetenekliler Eğitimi alanlarında uzman 3'er akademisyenlerden görüş ve öneriler alınarak son haline getirilmiştir. Eğitim öncesinde uygulanan anket ile öğrencilerin proje kapsamında verilen çevre eğitiminden beklentileri, çevre konularına yönelik farkındalık ve duyarlıklarının saptanması amaçlanmıştır. Eğitim sonrasında uygulanan anket ise proje kapsamındaki etkinliklerin öğrencilerin çevre farkındalık ve duyarlıklarına etkilerinin incelenmesi amacıyla uygulanmıştır. Elde edilen veriler analiz edilmeden önce Word programına yazılarak metin haline 
getirilmiştir. Elde edilen veriler betimsel analiz yöntemiyle analiz edilmiştir. Elde edilen veriler araştırma sorularından yola çıkılarak oluşturulan temalara göre sunulmuştur. Temalara göre geliştirilen kategorilere göre kodlamalar yapılmıştır. Araştırmada bireylerin görüşlerini yansıtmak amacıyla doğrudan alıntılara yer verilmiştir.

\section{Bulgular}

\section{Özel Yetenekli Öğrencilerin Çevre Eğitimi Projesinden Beklentileri}

Araştırmada uygulama öncesinde öğrencilerin çevre eğitimi projesine ilişkin beklentileri hakkında "Kâş̧ifler Doğada" Projesi kapsamındaki etkinliklerin size neler kazandırmasını bekliyorsunuz?" sorusu yöneltilmiştir. Öğrencilerin verdikleri cevaplardan elde edilen bulgulara Tablo 1 'de yer verilmiştir.

Tablo. 1. Özel Yetenekli Öğrencilerin Çevre Eğitimi Projesinden Beklentileri

\begin{tabular}{lc}
\hline Ífadeler & Ön uygulama (yüzde) \\
\hline Doğa hakkında bilgi/Doğayı tanıma & 52,2 \\
Doğa/çevre bilinci & 18,1 \\
Doğayı keşfetmek & 11,3 \\
Çevre duyarlılığı & 9 \\
Sanat ve Bilimle ilgili kazanımlar & 9 \\
Doğayı korumak için yapmamız gerekenleri öğretmesi & 6,8 \\
Ekosistemi öğretmesi & 6,8 \\
Yeni bakış açısı geliştirmek & 4,5 \\
Bilmiyorum & 4,5 \\
Yeni deneyimler & 4,5 \\
Doğa sevgisi & 4,5 \\
Çevre farkındalığı & 4,5 \\
\hline
\end{tabular}

Tablo 1'deki bulgular incelendiğinde öğrencilerin yarısından çoğu projede yer alan etkinliklerin kendilerine doğayı tanımaları ve doğa hakkında bilgi edinmeleri konusunda katkı sağlayacağını belirtmiştir. Bununla birlikte öğrenciler projenin çevre bilinci, çevre duyarlılığı, çevre farkındalığı, doğayı keşfetme, yeni bakış açıları geliştirme, doğa sevgisi, ekosistemi öğretme, yeni deneyimler kazandırma ve doğayı korumak için yapması gerekenleri öğretme gibi katkılar sağlayacağını düşünmektedir. Bu doğrultuda öğrencilerin görüşleri ele alındığında Katılımc 7 "Doğayla ilgili daha çok bilgi edinmeyi sağlayacaktır.” ifadesini kullanarak projenin doğa ile ilgili daha çok bilgi edinmelerini sağlayacağını belirtmiştir. Katılımcı 40 "Doğadaki canlıları daha yakından inceleyip bana onlar hakkında daha çok bilgi edindirmesini, beni bilmediğim bazı konularda aydınlatmasını ve beni doğaya yakınlaştırmasını bekliyorum." ifadesini kullanarak projenin doğa ile ilgili bilgi edinmelerini ve doğaya yakınlaşmalarını sağlayacağını vurgulamıştır. Katılımcı 11 "Bu projenin beni doğa ile ilgili bilinçlendirmesini ve bazl bilgiler vermesini bekliyorum." ifadesini kullanarak projenin kendisini bilgilendirmesinin yanında doğa ile ilgili bilinçlenmesini sağlayacağını vurgulamıştır. Katılımcı 28 ise "Özelikle doğa ve çevre bilincimin artması, ayrıca sanat ve bilimle ilgili kazanımlarımın olmasını bekliyorum." ifadesini kullanarak projenin çevre bilincinin yanında sanat ve bilimle ilgili kazanımlar edinmesini sağlayacağını vurgulamıştır. Katılımc1 39 "Doğanın gizli güzelliklerini keşfetmeyi ve o huzuru tatmayı amaçlıyorum. Doğayla daha yakından olabilmeyi ve bunun bana çevre bilincini ve çevre bilincinin faydalarını öğretmesini bekliyorum." ifadesini kullanarak projenin çevre bilincinin yanında doğayı keşfetmeyi sağlayacağını vurgulamıştır. Katılımcı 35 “Çevremizdekilerin fakına varmamızı sağlayacă̆ını, duyarlılığı artıracă̆ını umuyorum.” ifadesini kullanarak projenin çevre duyarlılığını artıracağını belirtmiştir. Katılımcı 6 "Teknolojisiz eğlenceli vakit geçirmek, doğayı keşfetmek, doğaya karşı yeni bir bakış açısı geliştirmek.” ifadesini kullanarak projenin yeni bir bakış açısı geliştirmesine katkı sağlayacağını vurgulamıştır. 


\section{Özel Yetenekli Öğrencilerin Çevre Duyarlıı̆̆ı}

Araştırmada uygulama öncesinde ve sonrasında çevreye karşı duyarlıklarını belirlemek için öğrencilere "Çevreye karşı duyarl bir birey olduğunuzu düşünüyor musunuz? Bu duyarlllı̆̆ınızı göstermek için neler yapıyorsunuz? Sizce bu yaptıklarınız sürdürülebilir bir çevre oluşturmak için yeterli midir?” soruları yöneltilmiştir. Tablo 2'de öğrencilerin ön testte ve son testte verdikleri cevaplardan elde edilen bulgulara yer verilmiştir.

Tablo. 2. Özel Yetenekli Öğrencilerin Çevre Duyarlılı̆̆ına İlişkin Görüşleri

Kategori Yüzde dă̆ı̆ım

\begin{tabular}{lcc}
\hline & Ön uygulama & Son Uygulama \\
\hline Çevreye karşı duyarlıyım & 93,1 & 72,7 \\
Çevreyi temiz tutuyorum & 63,6 & 40,9 \\
Yaptıklarım sürdürülebilir bir çevre için yeterli & 61,3 & 43,1 \\
değil & & \\
Ağaç dikiyorum & 13,6 & - \\
Doğaya zarar vermiyorum & 11,3 & - \\
Hayvanlara yardım ediyorum & 9 & 9 \\
Doğayı kirletenleri uyarıyorum & 9 & 29,5 \\
Yaptıklarım sürdürülebilir bir çevre için yeterli & 9 & 11,3 \\
İnsanları bilinçlendiriyorum & 9 & - \\
Enerji tasarrufu yapıyorum & 6,8 & 6,8 \\
Doğal kaynakları az kullanmaya çalışıorum & 4,5 & - \\
Geri dönüşüm yapıyorum & 4,5 & 11,3 \\
Çevreyi koruyorum & 4,5 & 15,9 \\
Canlılara zarar vermiyorum & 2,2 & - \\
Çevreye duyarlı değilim & 2,2 & - \\
Hayvanları koruyorum & - & 9 \\
Sivil toplum kuruluşuna katılabilirim & - & 11,3 \\
Proje ile birlikte daha duyarlıyım & - & 18,1 \\
Çevremiz için bütün insanlığın çaba sarf etmesi & 26 & 34 \\
gerekir. & & \\
Projeden sonra Dünya'ya daha fazla zarar & - & \\
verdiğimi anladım & & \\
Çevre için daha çok şey yapmam gerektiğini & & \\
anladım. & & \\
\hline
\end{tabular}

Tablo 2'deki bulgular değerlendirildiğinde uygulama öncesinde öğrencilerin çoğu çevreye duyarlı bir birey olduklarını, bu duyarlılı̆̆ çevreyi temiz tutarak, ağaç dikerek, çevreye zarar vermeyerek, insanları uyararak, geri dönüşüm yaparak gösterdiklerini belirtmiştir. Ayrıca öğrenciler yaptıklarının sürdürülebilir bir çevre için yeterli olmadığını belirtmiştir. Katılımcı 26 "Duyarlı olduğumu düşünüyorum. Çevreyi temiz tutmaya, hiçbir canlıya zarar vermemeye çalışlyorum. Hayır, çünkü toplum olarak bu bilince sahip değiliz. Bu beni çok üzüyor." ifadesini 
kullanarak duyarlı olduğunu fakat bunun sürdürülebilir bir çevre için yeterli olmadığını çünkü toplum olarak çevre bilincine sahip olmadığımızı vurgulamıştır. Katılımcı 6 ise "Evet, çünkü çöpümü doğada bırakmam çöpü gördügüm yerde kutusuna atarım. Hayvanlara yemek veririm. Hayır, yeterli değil çünkü ben ne kadar çabalasam da birçok insan doğayı kirletiyor." ifadesini kullanarak kendi çabalarının sürdürülebilir bir çevre için yeterli olmadığını belirtmiştir. Bazı katılımcılar çevre duyarlılıklarını çevreyi temiz tutmanın yanında insanları uyarma, hayvanları besleme, geri dönüşüm yapma gibi faaliyetler yaparak gösterdiğini fakat yaptıklarının sürdürülebilir bir çevre için yeterli olmadığını vurgulamıştır. Bu doğrultuda Katılımcı 37 “Evet, düşünüyorum. İlk olarak çevreyi temiz tutuyorum, enerji tasarrufuna katkl sağllyorum ve dikkat etmeyenleri uyarıyorum. Fakat bunları yalnız benim yapmam yeterli değil, başka insanlarında bu sorumluluklarl üstlenmesi gerekli.” ifadesini kullanmıştır. Bazı katılımcılar ise çevreye karşı duyarlı olduklarını ve yaptıklarının sürdürülebilir bir çevre için yeterli olduğunu vurgulamıştır. Bu doğrultuda Katılımc 11 "Bence çevreye karşı duyarlı biriyim. Duyarlılığımı göstermek için yere çöp atmıyorum, yerde çöp gördügüm zaman alıp çöpe atıyorum enerjileri israf etmiyorum vs. Bana göre bunlar sürdürülebilir bir çevre oluşturmaya yeter." ifadesini kullanarak yaptıklarının sürdürülebilir bir çevre için yeterli olduğunu belirtmiştir.

Tablo 2'deki bulgular değerlendirildiğinde uygulama sonrasında öğrencilerin büyük bir kısmı çevreye karşı duyarlı olduklarını belirtmiştir. Bazı öğrenciler aslında uygulama öncesinde duyarlılıklarının olmadığını, projeden sonra duyarlılıklarının arttığını, Dünya'ya daha fazla zarar verdiklerini anladıklarını belirtmiştir. Öğrenciler çevreye karşı duyarlılıklarını uygulama öncesinde olduğu gibi çevreyi temiz tutarak, koruyarak, insanları uyararak gösterdiğini belirtmiştir. Bazı öğrenciler proje ile birlikte çevre için daha çok şey yapması gerektiğini anladığını belirtmiştir. Ayrıca öğrenciler çevre için yaptıklarının sürdürülebilir bir çevre için yeterli olmadığını, kendileri dışındaki insanların da çevre için çaba sarf etmesi gerektiğini belirtmiştir. Bu doğrultuda Katılımcı 18 "Projeden önce pek duyarlı sayılmazdım. Projede anlatılanlar, gelecekte olabilecekler beni korkuttu. Bundan sonra yağları 3 kez kullandıracă̆ım ondan sonra okula veya belediyeye vereceğim. Kapakları toplayacă̆ım, kâğıt plastik, geri dönüştürülebilen atıkları geri dönüşüm kutusuna atacă̆ım." ifadesini kullanarak proje öncesine göre daha duyarlı olduğunu belirtmiştir. Buna benzer olarak Katılımcı 37 ise "Bu çalışmadan sonra çevreye karşı daha duyarlı bir birey oldum. Gittiğimiz yerdeki hayvanlara sevgi gösterdim, hiçbir bitkiye zarar vermedim, yerdeki çöpleri topladım. Ama maalesef bunlart yalnızca bizlerin yapmasl yeterli olmuyor." ifadesini kullanarak projeden sonra daha duyarlı olduğunu fakat sadece kendinin duyarlı olmasının yeterli olmadığını vurgulamıştır. Bazı katılımcılar projeden önce duyarlı olduklarını ve çevreyi yeterince koruduklarını ifade etiklerini düşünürken, proje sonrasında aslında yeterince duyarlı olmadıklarını anladıklarını vurgulamıştır. Bu doğrultuda Katılımcı 43 "Bu projeye başlamadan önce bu soruya evet demiştim. Fakat bu projeden sonra fark ettim ki gerçekten benim yaptıklarım da yeterli değilmiş. Bu yüzden duyarlı olma yolunda ilerlediğimi fakat bu ilerleyişin asla durmayacă̆ını düşünüyorum." ifadesini kullanarak proje sonrasında yaptıklarının yeterli olmadığını anladığını belirtmiştir. Proje sonrasında bazı öğrenciler çevre ile ilgili çevresindeki kişileri daha fazla uyaracağını çünkü sadece kendilerinin duyarlı olmasının sürdürülebilir bir çevre için yeterli olmayacağını vurgulamıştır. Bu doğrultuda Katılımcı 19 "Artık çevreye zararı bulunanları kızarak uyarmayı deneyeceğim fakat sadece benim yapmamla sürdürülebilir bir çevre olmaz. Ama öğrendiğime göre benim yaptı̆̆ım fayda bile birkaç şeyi kurtarabilir.” ifadesini kullanmıştır.

\section{Özel Yetenekli Öğrencilerin Çevre Bilinci}

Araştırmada uygulama öncesinde ve sonrasında öğrencilerin çevre bilincini belirlemeye yönelik öğrencilere "Çevre bilincine sahip bir birey olduğunuzu düşünüyor musunuz? Bu bilinç ile ekosistemi oluşturan canlı ve cansız bileşenlere yönelik nasıl bir tutum sergiliyorsunuz?” soruları yöneltilmiştir. Öğrencilerin verdikleri cevaplardan elde edilen bulgulara Tablo 3'de yer verilmiştir. 
Tablo. 3. Özel Yetenekli Öğrencilerin Çevre Bilincine İlişkin Görüşleri

\begin{tabular}{|c|c|c|}
\hline \multirow[t]{2}{*}{$\overline{\text { Kategori }}$} & \multicolumn{2}{|c|}{ Yüzde dağılım } \\
\hline & Ön Uygulama & Son Uygulama \\
\hline Çevre bilincine sahip olduğumu düşünüyorum & 95,4 & 88,6 \\
\hline $\begin{array}{l}\text { Çevredeki canlı ve cansız varlıkları } \\
\text { koruyorum }\end{array}$ & 50 & 68,1 \\
\hline Canlı ve cansız varlıklara iyi davranıyorum & 40,9 & - \\
\hline İnsanları uyarıyorum & 13,6 & - \\
\hline $\begin{array}{l}\text { Çevre bilincine kısmen sahip olduğumu } \\
\text { düşünüyorum }\end{array}$ & 6,8 & - \\
\hline $\begin{array}{l}\text { Çevre bilincine sahip olduğumu } \\
\text { düşünmüyorum }\end{array}$ & 2,2 & - \\
\hline $\begin{array}{l}\text { Çevreyi canlı ve cansız varlıkları daha çok } \\
\text { koruyacağım }\end{array}$ & - & 43,1 \\
\hline Projeden sonra çevre bilincim gelişti & - & 22,7 \\
\hline İnsanları daha çok uyaracağım & - & 9 \\
\hline
\end{tabular}

Tablo 3'deki bulgular değerlendirildiğinde uygulama öncesinde özel yetenekli öğrencilerin çoğu çevre bilincine sahip olduklarını belirtmişlerdir. Öğrencilerin çoğu, çevreyi, canlı ve cansız varlıkları koruduğunu ve onlara iyi davrandığını, buna karşılık ancak \%12'si çevrelerindeki diğer insanları çevre konusunda uyardığını belirtmiştir. Bu doğrultuda Katılımc1 4 "Evet düsünüyorum. Ekosistemde her canlının bir halkayı temsil ettiğini ve tek bir halkanın önemli olduğunu biliyorum. Bu yüzden doğaya zararlı ürünler kullanmıyorum ve hayvanların yaşam alanlarına zarar vermiyorum." ifadesini kullanarak çevre bilincine sahip olduğunu, ekosistemi oluşturan bileşenleri koruduğunu ve onlara zarar vermediğini vurgulamıştır. Katılımc1 11 "Çevre bilicine sahip biriyim. Aşırı avlanan insanları uyarıyorum, denizde yaşayan canlılar için denize çöp atmayıp denizdeki çöpleri topluyorum." ifadesini kullanarak çevreye zarar veren insanları uyardığını belirtmiştir. Katılımcı 34 "Evet, ekosistemi oluşturan hiçbir canliya zarar vermek istemem çünkü en ufak bir canlının bile besin zinciri yoluyla bütün canlılara zarar verebileceğini biliyorum." ifadesini kullanarak ekosistemdeki en ufak bir canlının zarar görmesinin besin zinciri yoluyla diğer canlıları etkileyeceğini vurgulamıştı. Bazı katılımcılar yeterince çevre bilincine sahip olmadıklarını belirtmiştir. Bu doğrultuda Katılımc1 3 "Hayır düşünmüyorum. Çünkü insan bazen duyarsız olabiliyor ve ister istemez canlı ve cansız varliklara" ifadesini kullanarak canlı ve cansız varlıklara zarar verebildiğini belirtmiştir. Buna benzer olarak Katılımc1 19 "Çevre bilincine çok sahip değilim ama elimden geldiğince tutumlu oluyorum." ifadesini kullanarak çevre bilincine sahip olmadığını fakat çevreyi korumak için elinden geldiğince gayret ettiğini vurgulamışıtr.

Tablo 3'deki bulgular değerlendirildiğinde proje sonrasında öğrencilerin büyük bir çoğunluğu çevre bilincine sahip olduklarını belirtmiştir; fakat ön testte yer alan yüzde ile kıyaslandığında düşme görülmüştür. Bu düşüş, öğrencilerin proje başında kendilerini çevre bilincine sahip olarak görürken, çevre bilinci hakkında eğitimler aldıktan sonra bu fikirlerinin değiştiğini ve aslında tam olarak bilinçli olmadıklarını fark ettiklerini göstermiştir. $\mathrm{Bu}$ doğrultuda 36 "Çevre bilincine sahip bir birey olduğumu bu projeden sonra düşünüyorum. Çünkü doğada yaşayan canlıların ekosistem içindeki yerinden tutun da yok oluşlarına kadar her şeyi en ince ayrıntısına kadar, değerli hocalar eşliğinde öğretti bize." ifadesini kullanarak proje sürecinde öğrendiği bilgilerin çevre bilincini geliştirdiğini belirtmiştir. Buna benzer olarak Katılımcı 5 "Evet, eskiyi bilmem de artık iyi bir tutum sergileyeceğim." ifadesini kullanarak çevreye karşı artık daha iyi tutum içinde olacağını vurgulamıştır. Katılımcı 19 ise "Bu projeden sonra çevre bilincine sahip olduğumu düşünüyorum. Ekosisteme karşı gayet nazik, kibar zarar vermemeye çalışan bir tutum sergileyeceğim." ifadesini kullanmışırı. Katılımc1 28 "Evet, düşünüyorum. Açıkçası bu projenin yarım olan bilincimi tamamladı̆̆ıma inaniyorum. Ekosistemi oluşturan canlı ve cansız bileşenleri 
elimden geldiğince bozmamaya doğal dengeye zarar vermemeye çalışacağım. ” ifadesini kullanarak projenin çevre bilincini geliştirdiğini canlı ve cansız bileşenleri koruma konusunda daha dikkatli olacağını vurgulamıştır. Buna benzer olarak Katılımc1 34 ise "Bu projeden sonra çevre bilicine sahip olduğumu düşünüyorum. Doğada bütün canlı ve cansızların uyum içinde yaşadığını ögrendiğim için hiç birine zarar vermemeye özen göstereceğim." ifadesini kullanmıştır.

\section{Özel Yetenekli Öğrencilerin Çevre Farkındalığı}

Araştırmada uygulama öncesinde ve sonrasında öğrencilerin çevre farkındalığını belirlemeye yönelik, öğrencilere "Çevre ile ilgili farkındalık sahibi misiniz? Çevresel farkındalı̆̆ınızın ne düzeyde olduğunu nedenleriyle birlikte değerlendirir misiniz?” soruları yöneltilmiştir. Öğrencilerin verdikleri cevaplardan elde edilen bulgulara Tablo 4'te yer verilmiştir.

Tablo. 4. Özel Yetenekli Öğrencilerin Çevre Farkındalığına İlişkin Görüşleri

\begin{tabular}{|c|c|c|}
\hline \multirow[b]{2}{*}{ İfadeler } & \multicolumn{2}{|c|}{ Yüzde dağılım } \\
\hline & Ön Uygulama & Son Uygulama \\
\hline Çevreyle ilgili farkındalık sahibiyim & 88,6 & 88,6 \\
\hline Orta düzeyde & 4,5 & 18,1 \\
\hline Çevreye ve canlılara önem veriyorum & 18,1 & - \\
\hline Çevreyi temiz tutuyorum & 13,6 & 15,9 \\
\hline Çevre ve canlılarla ilgili bilgim sınırlı & 13,6 & - \\
\hline Yüksek düzeyde & 11,3 & 20,4 \\
\hline Çevre ile ilgili farkındalık sahibi değilim & 9 & 2,2 \\
\hline Çevreye zarar vermiyorum & 6,8 & -- \\
\hline İnsanları çevreyle ilgili bilgilendiriyorum & 4,5 & - \\
\hline Çevreyle ilgili yeterince bir şey yapmıyorum & 4,5 & - \\
\hline Farkındalığım gittikçe gelişiyor & 2,2 & 4,5 \\
\hline Çöpleri doğaya attığım oluyor & 2,2 & - \\
\hline Ağaçlandıracak yer yok & 2,2 & - \\
\hline Ağaç dikiyorum & 2,2 & - \\
\hline Çevreye zarar verildiğinde tepki gösteririm & 2,2 & - \\
\hline Proje ile farkındalığım gelişti. & - & 40,9 \\
\hline Çevreyi koruyorum & - & 22,7 \\
\hline Çevre ile ilgili bilgi sahibiyim & - & 20,4 \\
\hline Çevreye nasıl davranacağımı biliyorum & - & 11,3 \\
\hline Çevreye nasıl etki ettiğimi biliyorum & - & 11,3 \\
\hline Geri dönüşüm yapıyorum & - & 6,8 \\
\hline
\end{tabular}

Tablo 4'deki bulgular değerlendirildiğinde öğrencilerin çoğu çevre farkındalığına sahip olduğunu belirtmiştir. Çevre farkındalığının yüksek düzeyde olduğunu belirten katılımcılar çevreye önem verdiklerini ve çevreye zarar verenleri uyardıklarını belirtmiştir. Bu doğrultuda Katılımcı 22 "Çevre ile ilgili farkındalı̆̆ımı iyi bir seviyede 
görüyorum. Ancak yine de daha çok farkındalıkta olmam gerekir.” ifadesini kullanarak farkındalığının yüksek olduğunu ama daha iyi olabileceğini belirtmiştir. Katılımcı 26 ise "Bence farkındalık sahibiyim. Çevresel farkındalı̆̆ım çok fazla çünkü canlılara ve hayvanlara çok önem veriyorum." ifadesini kullanarak çevre farkındalığının yüksek olduğunu, hayvanlara çok önem verdiğini vurgulamıştır. Çevre farkındalığına orta düzeyde sahip olan katılımcılar ise çevreye önem verdiklerini belirtmekle birlikte çevreyle ilgili bilgilerinin sınırlı olduğunu vurgulamıştır. Bu doğrultuda Katılımc1 15 "Çevreyi seviyorum ama çok fazla farkındalık sahibi değilim. Küresel ısınma ile ilgili şeyleri çok bilmiyorum.” ifadesini kullanarak çok fazla farkındalık sahibi olmadığını ve bilgi eksikliği olduğunu vurgulamıştır. Katılımcı 29 "Çevre ile ilgili farkındalık sahibiyim. Ama çevresel farkındalığımın çok üst düzeyde olduğunu düşünmüyorum. Çünkü sadece çevrenin önemini biliyorum ve zarar vermiyorum. Ama bunların dışında da çevreye karşı yapabileceğim şeyler de olabilir." ifadesini kullanarak çevrenin önemini bilip, çevreye zarar vermeme dışında yapılacak başka şeylerin olduğunu belirtmiştir. Bazı katılımcılar ise çevre farkındalığına sahip olmadığını belirmiştir. Bu doğrultuda Katılımcı 14 "Çevre ile ilgili farkındalık sahibi değilim.” ifadesini kullanırken, Katılımc1 23 "Aslında değilim. Diğer insanlarda çevreyi önemsiyorsa normal çünkü aşırı olarak doğa sevgim yok.” ifadesini kullanmıştır.

Tablo 4'deki bulgular değerlendirildiğinde uygulama sonrasında yine öğrencilerin çoğu çevre farkındalığına sahip olduğunu belirtmiştir. Öğrencilerin \%50'sine yakını proje süreci ile çevre farkındalıklarının geliştiğini belirtmiştir. Bu doğrultuda Katılımc 7 "Evet, bunun farkındayım. Yeterli düzeyde bu çevre eğitiminden önce neredeyse sıfır iken şimdi daha iyi." 'ifadesini kullanarak çevre eğitimi ile çevre farkındalığının arttığını belirtmiştir. Buna benzer olarak Katılımc 18 "Projeden sonra daha da arttı farkındalı̆̆ım. Çünkü kaynaklar tükenebilir, çocuklarımıza, torunlarımıza pis bir gelecek bırakabiliriz. Bu yüzden dikkatli kullanmalıyız.” ifadesini kullanarak proje süresince öğrendiklerinin çevre farkındalığını artırdığını vurgulamıştır. Araştırmada uygulama sonrasında bazı öğrencilerin uygulama öncesine göre farkındalık düzeylerinin arttı̆̆ı tespit edilmiştir. Bu doğrultuda Katılımcı 22 "Çevre farkındalığım iyi bir seviyedeydi. Ama proje sayesinde daha çok farkındalık kazandım.” ifadesini kullanmıştır. Buna benzer olarak Katılımc 39 "Çevreyle ilgili \% 85 farkındallk sahibiyim ki bu projeye katılmadan önce bu rakam \%60’lardaydı. Projeden sonra her küçük adımın birleşip kendiliğinden devasa adımlar olacă̆ını, bir kişiden ne olur demenin getireceği olumsuz sonuçları gördüm ve farkındalığım arttı." ifadesini kullanarak proje öncesine göre farkındalık düzeyinin arttığını belirtmiştir. Araştırmada proje sonrasında öğrencilerin çevre ile ilgili bilgi sahibi olma durumlarının arttığı ve bunun çevre farkındalıklarını artırdığı tespit edilmiştir. Bu doğrultuda Katılımc 19 “Önceden orta derecede olmama rağmen şu anda iyi derecedeyim. Çünkü bilmediğim şeyleri de ögrenmiş oldum.” ifadesini kullanarak bilgi düzeyinin artmasının farkındalığını artırdığını belirtmiştir. Buna benzer olarak Katılımc1 29 "Çevre ile ilgili farkındalık sahibiyim. Fakat farkındalı̆̆ımın önceden az olduğunu düşünüyordum. Ama kâşifler doğada projesinden sonra bu farkındalığımın yükseldiğini düşünüyorum. Çünkü çevreyle ilgili ĕglenerek bilgiler ögrendim.” ifadesini kullanarak proje süresince çevre ile ilgili edindiği bilgilerin çevre farkındalığını artırdığıını vurgulamıştır.

\section{Özel Yetenekli Öğrencilerin Ekolojik Sorumlulukları}

Araştırmada uygulama öncesinde ve sonrasında öğrencilerin ekolojik sorumluluklarını belirlemek için öğrencilerden "Ben çevreye karşı ekolojik sorumlulukları olan bir bireyim çünkü ................" ifadesini tamamlamaları istenmiştir. Öğrencilerin verdikleri cevaplardan elde edilen bulgulara Tablo 5 'te yer verilmiştir. 
Tablo. 5. Özel Yetenekli Öğrencilerin Ekolojik Sorumluluklarına İlişkin Görüşleri

\begin{tabular}{lcc}
\hline Kategori & \multicolumn{2}{c}{ Yüzde dağılım } \\
\hline Çevreyi koruyorum & Ön uygulama & Son Uygulama \\
Çevreyi temiz tutuyorum & 13,6 & 18,1 \\
Çevre yaşam kaynağımız & 13,6 & 6,8 \\
Çevreye zarar vermiyorum & 9 & 31,8 \\
Doğa geleceğimiz & 9 & - \\
Çevre yalnızca bize ait değil & 9 & 9 \\
Çevre kirliliğinin sonuçlarını biliyorum & 9 & 9 \\
Çevrenin parçasıyım & 6,8 & - \\
Çevre ekosistemimizi oluşturur & 6,8 & - \\
Çevreye dayanarak yaşıyorum & 4,5 & - \\
Çevremiz önemlidir & 4,5 & - \\
Çevreyle etkileşim içindeyiz & 2,2 & - \\
Çevreye nasıl davranacağımı biliyorum & 2,2 & - \\
Çevreye ihtiyacımız var & 2,2 & - \\
Çevre için yapmam gerekenler var & - & 11,3 \\
Çevreyi önemsiyorum & - & 9 \\
Çevre hepimizindir & - & 9 \\
Çevre bize emanettir & - & 9 \\
Çevrenin önemini anladım & - & 4,5 \\
İnsanları bilinçlendiriyorum & - & 4,5 \\
Çevre bilincine sahibim & - & 2,2 \\
\hline
\end{tabular}

Tablo 5'teki bulgular değerlendirildiğinde öğrencilerin büyük çoğunluğu çevreyle ilgili sorumlulukları olan bireyler olduklarını belirtmiş̧tir. Öğrenciler çevreyle ilgili sorumluluklarını çevreyi temiz tutma, koruma, zarar vermeme, çevrenin bir parçası olma, çevrenin yaşam kaynakları olması gibi nedenlerle açıklamıştır. Ayrıca çevrede yalnız olmadıklarını belirtmiştir. Bu doğrultuda Katılımcı 8 "Ben çevreye karşı ekolojik sorumlulukları olan bir bireyim çünkü Çevremde olanlar beni etkiliyor benim hareketlerim çevremi etkiliyor." ifadesini kullanarak çevre ile karşılıklı etkileşim içerisinde olduğunu bu yüzden ekolojik sorumluluk taşıdığını belirtmiştir. Katılımc 39 ise "Biz de bu çevrenin bir parçasıyız. Çevreye olan sorumluluklarımızı yerine getirmezsek eninde sonunda bu zararın ucu bize de dokunacak. Çünkü biz insanlarda ekosistemi oluşturan bir halkaylz. Kendi halkımızı yok etmek istemiyorsak çevremizi (diğer halkaları) da yok etmemeliyiz." ifadesini kullanarak çevreye verilen zararın eninde sonunda kendilerine dokunacağını bu yüzden ekolojik sorumluluk taşıdığını vurgulamıştır. Katılımc 3 "Dünya üzerinde sadece insanlar yoktur. İnsanlardan başka bir sürü canlılar vardır. Diğer canlıları da korumamız lazım." ifadesini kullanarak Dünya'da yalnız olmadığımızı ve diğer canlıları korumamız gerektiğinden ekolojik sorumluluk taşıdığını vurgulamıştır.

Tablo 5'teki bulgular değerlendirildiğinde uygulama sonrasında da öğrencilerin tamamı ekolojik sorumluluklar taşıdıklarını belirtmiştir. Öğrencilerin ekolojik sorumluluklarını çevrenin yaşam alanı olması, çevreyi koruma, çevreye duyulan ihtiyaç, çevreyi önemseme, çevrede yalnız olmama, çevrenin gelecek olması ve çevreyi temiz tutma gibi nedenlere dayandırdıkları tespit edilmiştir. Öğrencilerin ekolojik sorumluluklarını dayandırdıkları 
nedenlerin farklılaştığı, öğrencilerin çevrenin yaşam alanı olmasına ve çevreye duydukları ihtiyaca vurgu yaptıkları tespit edilmiştir. Bu doğrultuda Katılımcı 9 "Çevre bizim evimiz ona sahip çıkmalıyız." ifadesini kullanarak çevrenin yaşam alanları olmasının ekolojik sorumluluk taşımasının nedeni olduğunu vurgulamıştır. Katılımc 12 ise "Çevremiz geleceğimiz anlamına gelir. Yani çevremizi yok edip geleceğimizi yok etmemeliyiz." ifadesini kullanarak çevrenin insanların geleceği olmasının ekolojik sorumluluk taşımasının sebebi olduğunu vurgulamıştır. Katılımc1 26 ise "Bilinçliyim. Çevrenin yalnızca bize ait olmadı̆̆ını zarar verdiğimizde diğer tüm canlıların yaşamlarını tehlikeye soktuğumuzu biliyorum." ifadesiyle ekolojik sorumluluğunun nedenini çevrenin yalnızca insanlara ait olmadığını düşünmesi olarak belirtmiştir. Bazı katılımcılar projede öğrendiklerinin ekolojik sorumluluk taşımalarına katkı sağladığını belirtmiştir. Bu doğrultuda Katılımeı 15 "Çevrenin ne kadar değerli olduğunu ögrendim ve her parçasının ne kadar gerekli olduğunu ögrendim.” ifadesini kullanarak ekolojik sorumluluk taşıması ile projede öğrendiklerini arasında bağlantı kurmuştur.

\section{Özel Yetenekli Öğrencilerin Çevre Eğitimine İlişkin Görüşleri}

Araştırmada uygulama öncesinde ve sonrasında öğrencilerin çevre eğitimine ilişkin görüşlerini belirlemeye yönelik olarak öğrencilere "Çevre eğitimi sizce gerekli bir eğitim midir? Neden?”, "Çevre eğitimini zor, kolay, eğlenceli, sıkıcı... gibi kendinize ait bir ifade ile tanımlasanız bu ne olurdu?” soruları yöneltilmiştir. Öğrencilerin verdikleri cevaplardan elde edilen bulgulara Tablo 6'da yer verilmiştir.

Tablo. 6. Özel Yetenekli Öğrencilerin Çevre Eğitimine İlişkin Görüşleri

\begin{tabular}{|c|c|c|}
\hline \multirow[t]{2}{*}{ Kategori } & \multicolumn{2}{|c|}{ Yüzde dağılım } \\
\hline & Ön uygulama & Son Uygulama \\
\hline Çevre eğitimi gereklidir & 95,4 & 97,7 \\
\hline Çevre eğitimleri eğlencelidir & 63,6 & 75 \\
\hline Çevre bilinci geliştirmek için & 18,1 & 36,3 \\
\hline Çevreyi korumak için & 18,1 & 15,9 \\
\hline Çevreyi tanımak için & 15,9 & 6,8 \\
\hline Çevre duyarlılığ 1 geliştirmek için & 11,3 & - \\
\hline Çevre eğitimleri sıkıcıdır & 11,3 & 4,5 \\
\hline Çevre eğitimleri zevklidir & 9 & - \\
\hline Çevre eğitimleri eğiticidir & 9 & 13,6 \\
\hline Çevremizin temiz olması için & 9 & 9 \\
\hline Çevre eğitimleri zordur & 9 & - \\
\hline Çevremizin daha güzel olması için & 4,5 & - \\
\hline Çevre yaşam kaynağımız & 4,5 & 13,6 \\
\hline Çevreyi yaşayarak öğrenmeliyiz & 4,5 & - \\
\hline İnsanların çevrenin önemini anlamaları için & 2,2 & 4,5 \\
\hline Çevre farkındalığ 1 geliştirmek için & 2,2 & 4,5 \\
\hline Proje ile çevre eğitiminin önemini anladım & - & 11,3 \\
\hline Çevre eğitimleri ilginçtir & - & 9 \\
\hline Çevre ile ilgili bilgi edinmek için & - & 9 \\
\hline Çevre eğitimleri zordur & - & 9 \\
\hline İnsanlar davranışlarının çevreye etkilerini bilmeli & - & 6,8 \\
\hline Çevreye saygı duymayı sağlar & - & 4,5 \\
\hline
\end{tabular}


Tablo 6'daki bulgular değerlendirildiğinde uygulama öncesinde öğrenciler çevre eğitiminin çevreyi tanımak, çevreyi korumak, çevrenin temiz olması, çevre bilinci ve duyarlılığı geliştirmek için gerekli olduğunu belirtmişlerdir. Öğrencilerin çoğu çevre eğitimlerinin eğlenceli olduğunu belirtirken; çevre eğitimlerinin sıkıc1, zor, zevkli, eğitici, merak uyandırıcı, heyecan verici ve ilginç olduğunu belirten öğrenciler de olmuştur. Bu doğrultuda Katılımcı 16 "Evet, gereklidir. Çünkü çevremizi temiz tutmanın önemini ve gerekliliğini her birey ögrenmelidir." ifadesini kullanarak çevre eğitimi ile her bireyin çevrenin önemini anlayacağını vurgulamıştır. Katılımc1 19 ise "Bence gereklidir. Çünkü şu anda bilinçsizler yüzünden çevreye tahmin ettiğimizden de büyük bir zarar veriyoruz." ifadesini kullanarak çevre eğitiminin çevre bilinci için gerekli olduğunu vurgulamıştır. Katılımcı 33 "Bence bu ĕgitimin herkese zorunlu olması gerekiyor. Çünkü yaşamamızı sağlayan ortam çevremizdir. Yiyeceğimizi, içeceğimizi havamızı buradan sağlarız.” ifadesini kullanarak çevre eğitiminin zorunlu olması gerektiğini çünkü çevrenin yaşam alanımız olduğunu vurgulamıştır. Katılımc1 39 "Evet, nedeni ise çevre bilinci yetişmeyen bireyin hayvanlara, bitkilere, doğaya saygısı olmayan bireyin ne topluma ne kendine saygisl yok demektir. Bu yüzden daha küçük yaştan çevre bilinci değeri çocuğa kazandırılmalıdır." ifadesini kullanarak çevre eğitiminin küçük yaşlarda çevre bilinci kazandırmak için gerekli olduğunu vurgulamıştır.

Tablo 6'daki bulgular değerlendirildiğinde uygulama sonrasında da uygulama öncesinde olduğu gibi öğrencilerin tamamı çevre eğitiminin gerekli olduğunu belirtmiştir. Öğrenciler çevre eğitimlerinin çevre bilincini geliştirmek, çevreyi korumak, çevreyi temiz tutmak, çevre ile ilgili bilgi edinmek, çevreyi tanımak için gerekli olduğunu vurgulamıştır. Uygulama öncesine göre çevre eğitimlerinin eğlenceli, eğitici, ilginç olduğunu belirten öğrencilerin sayısı artmıştır. Bununla birlikte çevre eğitimlerinin zor olduğunu belirten öğrencilerin sayısı azalmıştır. Katılımcıların görüşleri ele alındığında Katılımcı 11 "Bence gereklidir. Çünkü eğer insanları bu konu hakkında ĕgitim almazsa veya bilinçlendirilmezse dünyamızın sonu hiç hayra alamet değil." ifadesini kullanarak çevre eğitiminin yaşanabilir bir Dünya için gerekli olduğunu belirtmiştir. Katılımcı 5 ise "Kesinlikle. Çünkü dünya hepimizin hepimiz Dünya 'ya karşı sorumluluk sahibi olmalıyı. Yoksa Dünya nın sonu gelir.” ifadesini kullanarak çevre eğitimlerinin çevreye karşı sorumluluk sahibi olmayı sağlayacağını vurgulamıştır. Araştırmada bazı katılımcılar projedeki çevre eğitimiyle beraber çevre eğitiminin ne kadar önemli olduğunu anladığını belirtmiştir. Katılımcı 19 ise "Fazlasılla gerekli çünkü mesela biz çevre eğitimi aldıktan sonra çevreyi daha iyi korumaya çalışacă̆ız. Ĕger ki bu ĕgitim herkese verilirse çevrenin ne kadar güzel olacă̆ını tahmin bile edemiyorum." ifadesini kullanarak aldıkları çevre eğitimiyle çevreyi daha çok koruyacağını belirtmiştir.

\section{Özel Yetenekli Öğrencilerin Çevre Eğitimi Projesinden Beklentilerinin Karşılanma Durumu}

Araştırmada uygulama sonrasında öğrencilerin çevre eğitimi projesine ilişkin beklentilerinin karşılanıp karşılanmadığının belirlenmesi için öğrencilere “Kâş̧ifler Doğada” Projesi kapsamındaki etkinlikler size neler kazandırdı? "sorusu yöneltilmiştir. Öğrencilerin verdikleri cevaplardan elde edilen bulgulara Tablo 7'de yer verilmiştir.

Tablo. 7. Özel Yetenekli Öğrencilerin Çevre Eğitimi Projesine İlişkin Görüşleri

\begin{tabular}{lc}
\hline İfadeler & Son uygulama (yüzde) \\
\hline Çevre bilinci kazandırdı & 29,5 \\
Doğa hakkında bilgilendirdi & 29,5 \\
Ekosistemi öğrendim & 25 \\
Ekolojik ayak izimi öğrendim & 15,9 \\
Çevreyi korumaya teşvik etti & 15,9 \\
Bitki türlerini öğrendim & 13,6 \\
Çevreye karşı sorumluluklarımı öğretti & 9 \\
Çevreye bakış açımı değiştirdi & 9 \\
Farklı ekosistemleri tanıdım & 9 \\
Fosilleri öğrendim & 9 \\
Karbon ayak izimi öğrendim & 9
\end{tabular}




$\begin{array}{lc}\text { Hayvan türlerini öğrendim } & 9 \\ \text { Doğa sevgisi kazandırdı } & 9 \\ \text { İpek böceklerinin yaşamları } & 6,8 \\ \text { Çevre duyarlılığı kazandırdı } & 6,8 \\ \text { Çevre farkındalığımı artırdı } & 6,8 \\ \text { Çevrenin önemini kavrattı } & 6,8 \\ \text { Asit yağmurlarını öğrendim } & 6,8 \\ \text { Farklı bilim dallarının doğa ile ilişkisi } & 4,5 \\ \text { Doğayı keşfetmemi sağladı } & 2,2 \\ \text { Yaşama sevinci ve umut kazandırdı } & 2,2\end{array}$

Tablo 7'deki bulgular değerlendirildiğinde uygulama sonrasında öğrenciler çevre eğitimi projesinde beklentilerinin karşılandığını belirtmiştir. Öğrenciler söz konusu çevre eğitimi projesinde çevre ve ekosistem hakkında bilgi, çevre bilinci, çevre duyarlılığı ve farkındalığı kazandığını belirtmiştir. Ayrıca öğrenciler projenin kendilerini çevreyi korumaya teşvik ettiğini, doğa sevgisi kazandırdığını ve çevreye karşı sorumluluklarını öğrettiğini belirtmiş̧ir. Bu doğrultuda Katılımc1 5 "Bana çok iyi, tamda aradığım şekilde bir doğa bilinci kazandırdl." ifadesini kullanarak projenin kendisine çevre bilinci kazandırdı̆̆ını vurgulamıştır. Katılımc1 42 ise "Çevre karşı olan bilincimi artırdı. Farklı grup etkinlikleri ile grup çalışmasının nasıl yapılacağın anlattı. Ekosistem hakkında fazlası ile önemli ve faydalı bilgiler aktard. İpek böcekleri ile kişisel sorumluluğumu artırdl. Sorgulamamı artırdı. Bazı bildiğim yanlışların doğrularını ögretti." ifadesini kullanarak projenin çevre bilincini artırdığını, bilgilendirdiğini ve sorumluluklarını öğrettiğini vurgulamıştır. Projenin kendilerine, çevreye karşı farklı bakış açlları kazandırdığını Katılımc1 12 "Proje beklediklerimin hepsini kazandırdl. Çevreye ve canlılara baklş açım değişti." ifadesini, Katılımc1 37 ise "Doğaya eskisinden daha farkll baklyorum. Hiç denemediğim şeyleri yaptım. Hiç duymadığım bilgileri öğrendim." ifadesini kullanarak vurgulamıştır. Katılımcı 39 "Proje hayata ve çevreye bakış açımı değiştirdi. Çevreye katkı ve yardım için çok büyü projeler olmasına gerek olmadığını yaptığımız küçük yardımların bile çevremizi etkilediğini bilelim." ifadesini kullanarak çevreye yapılan küçük katkıların da çok önemli olduğunu belirtmiştir. Katılımc1 9 ise "Beni doğayla tanışırıdı. Doğayla iç içe yaptı. Ekosistem ve diğer kavramları ĕglenceli ve uygulamalı şekilde bize ögrretti." ifadesini kullanarak projenin eğlenceli ve uygulamalı bir şekilde çeşitli bilgiler sağladığını vurgulamıştır.

\section{Tartışma ve Sonuç}

Bu çalışmada, TÜBİTAK 4004 "Bilim ve Sanat Kâşifleri Doğada" adlı proje kapsamında akademisyenler ve öğretmenler tarafından geliştirilen etkinliklerle altı gün boyunca devam eden doğa eğitiminin, özel yetenekli öğrencilerin çevreye yönelik farkındalık ve duyarlılıklarına etkisi araştırılmıştır. Eğitimlerden önce ve sonra uygulanan anketlerle veriler toplanmış ve betimsel analiz yapılmıştır. Elde edilen bulgulara dayalı olarak özel yetenekli öğrencilerin uygulama başında da sonunda da çevreye karşı duyarlı oldukları ve olumlu tutum sergilediklerini düşündükleri ortaya çıkmıştır. Daha önce yapılan çalışmalarda da özel yetenekli öğrencilerin çevreye yönelik tutumlarının olumlu olduğu (Esen, 2011; Aydın, Coşkun, Kaya ve Erdönmez, 2011; Bakar ve Aydınl, 2012; Uğulu, Akkaya \& Erkol, 201) ve hatta çevrelerine yönelik olumlu tutumlarının ve hassasiyetlerinin normal zihin düzeyinde olan yaşıtlarından anlamlı derecede farklılık gösterdiği ortaya çıkmıştır (Uğulu, 2013; Sontay, Gökdere \& Usta, 2014; 2016). Araştırma bulgularına bakıldığında ise verilen eğitim sonrasında çevreye karşı duyarlı olduğunu düşünen bireylerin sayısında azalma olmuştur; çünkü proje kapsamında alınan eğitimler sonucunda bireylerin proje başında çevreye karşı duyarlı olduklarını düşündükleri ama eğitimler sayesinde artan farkındalık ve duyarlılıkları ile çevrenin korunması ve duyarlılık geliştirilmesi için daha fazla çaba sarf etmek zorunda olduklarını fark ettikleri ortaya çıkmıştır. Örneğin uygulamalar öncesinde çevreyi temiz tuttuğunu ve yaptıklarının sürdürülebilir bir çevre için yeterli olduğunu belirten öğrenci sayısında \%20'nin üzerinde azalma olmuştur. Elde edilen sonuçlar, öğrencilerin proje kapsamındaki eğitimlerle çevreye karşı farkındalıklarının, duyarlılıklarının ve bilinçlerinin geliştiğini, çevreyi daha çok korumaya başladıklarını, geri dönüşüme önem vermeye başladıklarını ve bunu davranışa dönüştürdüklerini ortaya koymuştur. Etkin bir çevre eğitiminin öncelikli amacı bireylerin çevreye yönelik davranışlarını olumlu yönde şekillendirmektir ve davranış değişikliğinde de 
tutumların değişmesi önemlidir (Bradley, Waliczek \& Zajicek, 1999). Özel yetenekli öğrenciler çevre, çevre sorunları ve bunların çözümüne yönelik daha fazla bilgiye sahip olduklarında bu problemlerin önlenmesi ve çözümlenmesi için üst düzeyde düşünmekte ve daha fazla hassasiyet geliştirerek karar verici konumda olabilmektedirler (Winocur ve Maurer, 1991; Clark, 1992; Esen, 2011). Mevcut çalışmada da altı gün boyunca süren doğanın tanınması, korunması, sürdürülebilirliği, çevre problemleri ve çözümler vb. konularda akademisyenler ve öğretmenler tarafından verilen eğitimler sonrasında özel yetenekli öğrencilerin çevre ile ilgili sorulan sorulara daha farkında cevaplar verdikleri ve artık bilgilerini davranışa dönüştürmeye başladıkları, dolayısıyla çevreye karşı duyarlıklarının arttığı gözlenmiştir. Bu noktada proje kapsamında verilen çevreye yönelik eğitimlerin, öğrencilerin çevreye yönelik tutumlarında ve davranışlarında olumlu etkiler yarattığı söylenebilir.

Bunlarla birlikte proje kapsamında etkinlikler bilim ve sanat merkezindeki sınıf ortamlarıyla sınırlı kalmamış, İstanbul Üniversitesi derslikleri ve Botanik Bahçesi, Belgrad Ormanı ve Atatürk Arboretumu gibi öğrencilerin doğayı ve içinde barındırdıklarını doğrudan gözlemleyip, deneyimleyebilecekleri alan gezileri gerçekleştirilmiş ve okul dişı ortamlar kullanılmıştır. Çalışmada öğrencilerden elde edilen cevaplar doğrultusunda öğrencilerin okul dışı öğrenme ortamlarında eğlenerek öğrendiklerini, daha etkili öğrenmeler gerçekleştirdiklerini ifade ettikleri görülmüştür. Sebasto ve Cavern (2006), çevre eğitim öğrencilerin açık havada yapılan etkinliklerde eğlenerek öğrendiklerini ifade ederken; DiEnno ve Hilton (2005), çevre eğitiminde yapılan alan gezilerinin çevreye yönelik olumlu tutum geliştirmede önemli etkisi olduğunu belirtmektedir. Bu bağlamda çevreye yönelik duyarlılıkların ve farkındalıkların; genel olarak çevreye yönelik olumlu tutumların gelişmesinde proje eğitimleri kapsamında sağlanan okul dişı faaliyetlerin etkili olduğu söylenebilir. Öğrencilerin proje eğitim sürecinde eğlenerek öğrenmelerinin bir diğer sebebi ise, çalışmanın sadece öğrencilerin çevre konusunda teorik bilgiler elde etmelerine odaklanan bir eğitim anlayışında planlanmaması gösterilebilir. Çünkü bu eğitim sürecinde öğrencilerin çevre temalı resimler çizmiş, doğada var olan malzemelerle çeşitli objeler tasarlamış, ormanda yaşayan varlıkların farkına varabilmek için doğayı dinlemiş, bir canlının gelişiminin farkına varabilmek için tırtılın kelebek oluşunu takip etmiş, kendi karbon ayak izlerini hesaplamış, doğada buldukları malzemelerden oyunlar tasarlamış ve bunlar gibi pek çok etkinlik gerçekleştirmiştir. Yine öğrencilerin proje sonucunda verdikleri cevaplarda eğlenerek ögrendiklerini ifade etmelerinde bu çalışmaların etkili olduğu söylenebilir.

Yukarıda bahsedilen noktalar ışığında, çevreye ve çevrenin korunmasına yönelik kişilik yapıları gereği hassasiyetleri olan özel yetenekli öğrencilerin, çevreye yönelik eğitim alarak daha fazla farkındalık ve duyarlık kazanması; daha olumlu tutumlara sahip olması ve var olan durumlara yaratıcı çözümler getirebilmeleri mümkündür. Bu yüzden etkili sonuçların elde edilebilmesi için benzer çalışmalarla, özellikle sınıf dışı öğrenme ortamlarında yürütülen etkinliklerle; daha uzun süreli eğitimlerin gerçekleştirilmesi önerilebilir.

\section{Teşekkür}

117B072 nolu proje kapsamında çalışmaya verdiği katkılardan dolayı TÜBİTAK’a teşekkürlerimizi sunarız. 


\section{References}

Aydın, F., Coşkun, M., Kaya, H., \& Erdönmez, İ. (2011). Gifted students' attitudes towards environment: A case study from Turkey. African Journal of Agricultural Research, 6(7), 1876-1883.

Bakar, F., \& Aydınlı, B. (2012). Bilim ve sanat merkezi öğrencilerinin plastik ve plastik atıkların geri dönüşümü ve çevreye etkileri konularında tutumlarının belirlenmesi. [Determination of the attitudes of students of science and arts center on the recycling of plastics and plastic wastes and their effects on the environment]. X. National Science and Mathematics Education Congress-30 June, 2012, Niğde Univercity.

Birinci, N., (2007), Kurum ve kuruluşların ön sözleri, [Preamble of institutions and organizations ]. Yeşil Kutu Teacher's Handbook, X-press Printing, Turkey

Çağlar, D. (1972). Üstün zekâlı çocukların özellikleri. [Characteristics of gifted children]. Journal of Ankara University Faculty of Education, Ankara, 5(3), 95 - 110.

Clark, B. (1992). Growing up gifted: Developing the potential of children at home and at school(4th ed.). New York: Merrill.

Budak, B., (2008). İlköğretim kurumlarında çevre eğitiminin yeri ve uygulama çalışmaları, [The place of environmental education in primary education institutions and application studies]. Graduate Thesis, Ege University Graduate School of Natural and Applied Sciences.Izmir

Erten, S., (2003). 5. sınıf öğrencilerinde "çöplerin azaltılması" bilincinin kazandırılmasına yönelik bir öğretim modeli.[An instructional model for gifting 5th grade students to reduce "trash reduction"]. Hacettepe University Journal of Education,, 25, 94-103.

Erten, S., (2005). Okul öncesi öğretmen adaylarında çevre dostu davranışların araştırılması.[Investigation of environment friendly behaviors in preschool teacher candidates]. Hacettepe University Journal of Education, 28, 91-100.

Esen, T. (2011). Üstün yetenekli ögrrencilerin çevreye yönelik bilgi ve tutumlarının incelenmesi. [Investigating the knowledge and attitudes of gifted students towards the environment]. Master Thesis. Adiyaman University. Adıyaman.

Gould, J. C.,Weeks, V., \& Evans, S. (2003). Science starts early. Gifted Child Today, 26(3), 38-42.

Hart, P. (2007). Environmental education. In Sandra Abelland Norman Lederman (Eds.). Handbook of research on science education (pp.689-729). New Jersey, USA: Lawrence Erlbaum.

Karnes, F. A., \& Riley, T. L. (1999). Developing an early passion for science through competitions. Gifted Child Today, 22(3), 35-38.

Kopelman, M., Galasso, V. G., \& Strom, P. (1977). A model program for the development of creativity in science. Gifted Child Quarterly, 21(1),80-84.

IUCN (1970). International working meeting on environmental education in the school curriculum final report. Gland: Switzerland

Lovecky, D. V. (1993). The quest formeaning: Counseling issues with gifted children and adolescents. In L. K. Silverman (Ed.), Counseling The Gifted and Talented (pp. 29-47). Denver: LovePublishingCompany.

Meador, K. S. (2003). Thinking creatively about science: Suggestions for primary teachers. Gifted Child Today, 26(1), 25-29.

Mönks, F. J.,Heller, K. A., \& Passow, H. A. (2002). The study of giftedness: Reflections on where weare and where we are going. In K. A. Heller, F. J. Mönks, R. J. Sternberg\& R. F. Subotnik (Eds.), International handbook of giftedness and talent(2nd ed.) (pp. 839-863). Oxford: Elsevier.

Neal, P., \& Palmer, J., (1994). The handbook of environmental education. Routledge, New York, 9870415093149.

Ngoi, M., \& Vondracek, M. (2004). Working with gifted science students in a public high school environment. Journal of Secondary Gifted Education, 15(4), 141-147. 
Piechowski, M. M. (1997). Emotional giftedness: Themeasure of intrapersona lintelligence. In N. Colangelo \& G. A. Davis (Eds.) Handbook of Gifted Education (2nd ed.) (pp. 366-381). Boston: Allyn\& Bacon.

Sarıkaya, H. Z., (2007). Kurum ve kuruluşların ön sözleri, [Preamble of institutions and organizations ]. Yeşil Kutu Teacher's Handbook, X-press Printing, Turkey

Sisk, D. (2007). Differentiation for effective instruction in science. Gifted Education International, 23, 32-45.

Smutny, J.,\& VonFremd, S. E. (2004). Differentiating for the young child. Thous and Oaks: CorwinPress.

Sontay, G., Gökdere, M., \& Usta, E. (2014). Üstün yetenekli öğrencilerle akranlarının çevresel davranışlarının karşılaştırmalı incelenmesi. [A comparative study of environmental behaviors of peers with gifted students]. Journal of Turkish Gifted and Talented, 4(2), 90-106.

Sontay, G., Gökdere, M., \& Usta, E. (2016). Üstün yetenekli öğrencilerle akranlarının çevre okuryazarlık bileşenleri açısından karşılaştırmalı incelenmesi. [A comparative study of gifted students in terms of environmental literacy components]. Journal of Turkish Science Education, 13(2), 28-46.

Şimşekli, Y., (2004). Çevre bilincinin geliştirilmesine yönelik çevre eğitimi etkinliklerine ilköğretim okullarının duyarlılığı. [Sensitivity of primary schools to environmental education activities for the development of environmental awareness]. Journal of Uludag University Faculty of Education, 17(1), 83-92.

Taylor, N., Littledyke, M., Eames, C., \& Coll, R. K., (2009). An international perspective on the development of environmental education. Environmental Education in Context, Sense Publishers, The Netherlands, 9789087909611.

Uğulu, İ. (2013). Üstün zekalı/yetenekli öğrenciler ile normal gelişim gösteren öğrencilerin çevreye yönelik tutumlarının karşılaştırılması. [ Comparison of gifted / talented students and normal-oriented students' attitudes towards the environment]. Journal of Buca Education Faculty, 35, 1-14.

Uğulu, İ., Akkaya, Z., \& Erkol, S. (2013). An investigation on environmental attitudes of gifted students and the assessments in terms of some demographic variables. E-Journal of New World Sciences Academy. NWSAEducationSciences, 8(4), 400-410. DOI: 10.12739/NWSA.2013.8.4.1C0595.

Zeleny, L. C., \& Schultz, W., (2000). Promoting environmentalism, Journal of Social Issues, 56 (3), 365-371.

Winocur, S. L.,\& Maurer, P. A. (1991). Critical thinking and gifted students: Using impact to improve teaching and learning. In N. Colangelo\& G. Davis (Eds.), Handbook of Gifted Education(pp. 308-317). Boston: Allyn\& Bacon. 